Historic, archived document

Do not assume content reflects current scientific knowledge, policies, or practices. 

a S多1

1945069

RESERVE

\section{$2{ }^{4}$ National Animal Disease Center.}

Guidelines and Bibliography, //
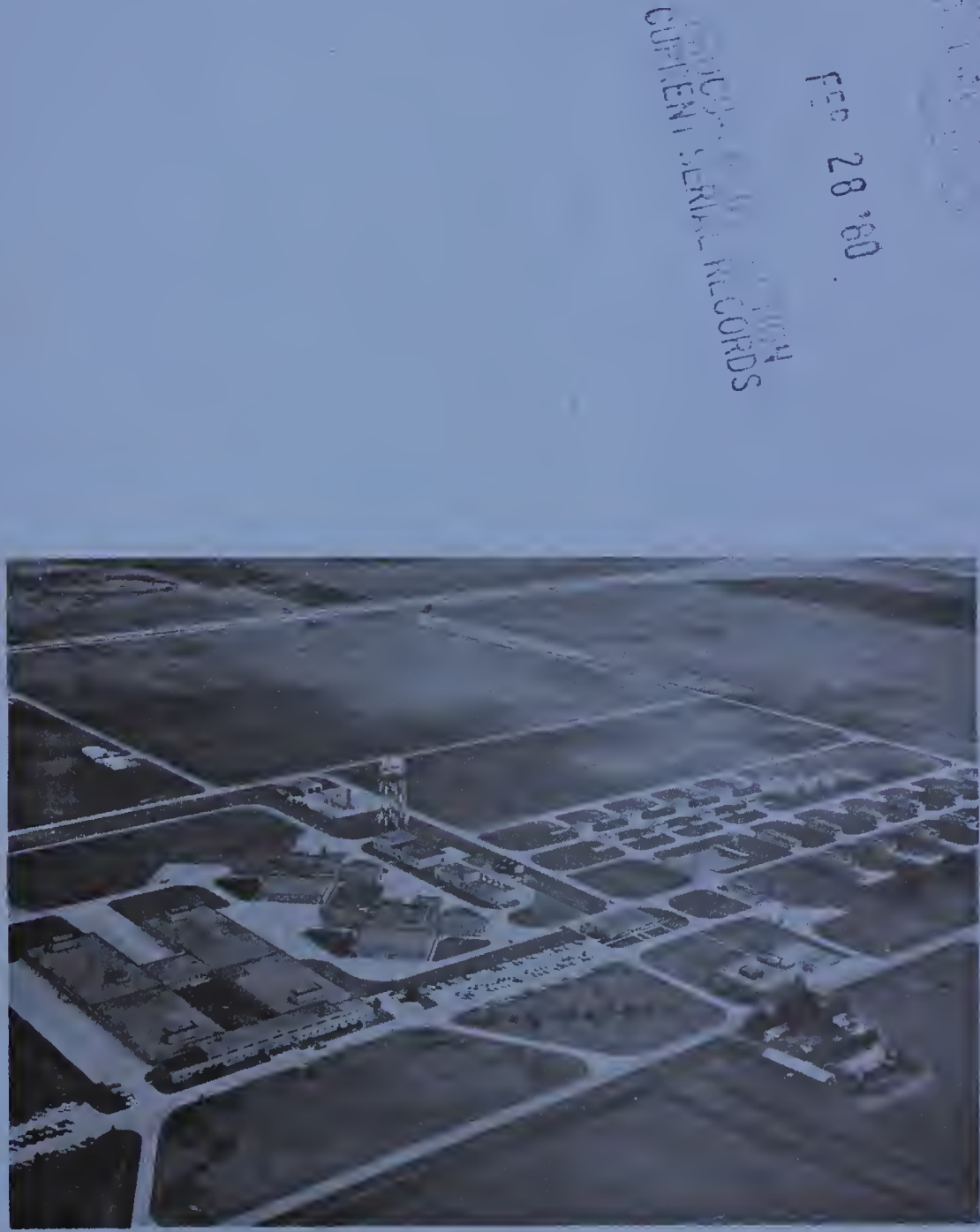

Agricultural Reviews and Manuals

Science and Education Administration

U.S. Department of Agriculture 
865806 
The United States Department of Agriculture established the National Animal Disease Center on July 27, 1956, when President Dwight D. Eisenhower signed the appropriation bill containing the $\$ 16,250,000$ to construct the new laboratory. The mission of the Center was, and continues to be, to conduct basic and applied research on the diseases of livestock and poultry of major economic importance to agriculture. Its staff of approximately 350 employees is committed to excellence in veterinary research and to an interdisciplinary approach to finding solutions to animal health problems. Efforts of the Center's 60 research scientists are devoted to the study of approximately 30 diseases or disease complexes affecting cattle, swine, poultry, sheep, horses and other animals. This strong and broadly based intramural research program is supplemented by an extensive extramural program of research projects at $24 \mathrm{U} . \mathrm{S}$. universities supported in part by Agency funds. In addition, cooperative research is also in progress with veterinary research colleagues in Egypt, India, and Pakistan.

This report of the research program of the National Animal Disease Center is prepared and disseminated to interested colleagues throughout the world to foster scientific understanding and to stimulate the interaction so necessary among those who have chosen to serve man and his animals.

P. A. O'Berry, Director National Animal Disease Center Ames, Iowa

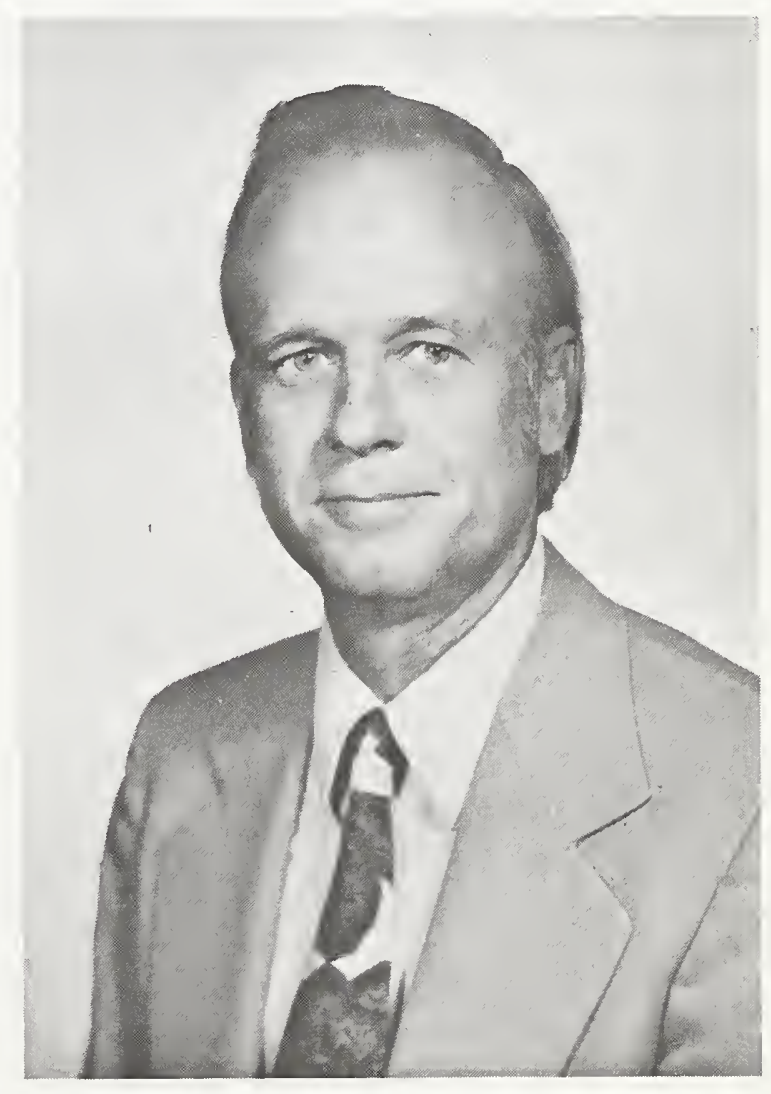


CONTENTS

Bacteriological and Mycological Research Laboratory . . . . . . . . . . . 1

Bovine Mastitis . . . . . . . . . . . . . . . . . . . . . . 1

Bovine Brucellosis . . . . . . . . . . . . . . . . . . . . . . 3

Reproductive Diseases of Cattle . . . . . . . . . . . . . . . . . . . 4

Leptospirosis of Cattle . . . . . . . . . . . . . . . . . . . . . . 5

Infectious Bovine Keratoconjunctivitis (Pinkeye) of Cattle . . . . . . 7

Paratuberculosis of Cattle . . . . . . . . . . . . . . . . . . 9

Mycobacteriosis of Swine . . . . . . . . . . . . . . . . . . 10

Swine Erysipelas . . . . . . . . . . . . . . . . . . . . . . 10

Streptococcic Lymphadenitis of Swine (Jowl Abscesses) . . . . . . . . . . 11

Swine Dysentery . . . . . . . . . . . . . . . . . . . . . 12

Mycoses and Mycotoxises . . . . . . . . . . . . . . . . . . . 13

Pasteurellosis (Fowl Cholera) . . . . . . . . . . . . . . . . . . 15

Turkey Airsacculitis . . . . . . . . . . . . . . . . . . . . 17

Biochemistry and Biophysics Research Laboratory . . . . . . . . . . . . 18

Microbial Section . . . . . . . . . . . . . . . . . . . . 19

Analytical section . . . . . . . . . . . . . . . . . . . 20

Immunological section . . . . . . . . . . . . . . . . . . . . 21

Pathological Research Laboratory . . . . . . . . . . . . . . . . 24

Calf Scours . . . . . . . . . . . . . . . . . . . . . . . 25

Respiratory Diseases of Sheep . . . . . . . . . . . . . . . . . 26

Respiratory and Septicemic Diseases of Poultry . . . . . . . . . . . . 27

Hematologic Diseases of Horses and Cattle . . . . . . . . . . . . . . 28

Bovine Lymphosarcoma . . . . . . . . . . . . . . . . . . . . . 29

Virological Research Laboratory . . . . . . . . . . . . . . . . 30

Enteric Diseases of Cattle . . . . . . . . . . . . . . . . . 30

Respiratory and Reproductive Diseases of Swine . . . . . . . . . . . . 32

Viral Enteric Diseases of Swine . . . . . . . . . . . . . . . . 33

Ornithosis in Poultry . . . . . . . . . . . . . . . . . . . . 34

Pseudorabies .. . . . . . . . . . . . . . . . . . . . 35

Respiratory Diseases of Cattle . . . . . . . . . . . . . . . 36

Physiopathology Research Laboratory . . . . . . . . . . . . . . . 37

Gastroenteric Physiology . . . . . . . . . . . . . . . . . . . 38

Mineral Metabolism Studies . . . . . . . . . . . . . . . . . 39

Gastrointestinal Microbiology . . . . . . . . . . . . . . . . . . . . . 41

Development of Radio Telemetry System for Transmitting Physiologic Data . 42

Biological Safety Unit . . . . . . . . . . . . . . . . . . 43

Biological Laboratory Safety Research . . . . . . . . . . . . . . . 44 
BACTERIOLOGICAL AND MYCOLOGICAL RESEARCH LABORATORY

AC Pier, DVM, PhD, Dipl ACVM--Chief Teri D McClannahan--Secretary

Scientists in the Bacteriological and Mycological Research Laboratory at the National Animal Disease Center (NADC) conduct original and meaningful research on diseases of food-producing animals that are caused or mediated by bacterial or fungal agents. Research projects encompass studies emphasizing agents and agent-host interactions. Studies of the agent include isolation, identification, nutrition, metabolism, antigenic and chemical analysis, and taxonomy. Studies emphasizing agent-host interaction include aspects of infection, disease, intoxication, epizootiology, pathogenesis, immunology, and chemotherapy. Research objectives are to develop sufficient knowledge on new diseases on which to base program diagnosing, controlling, or eradicating established diseases that cause significant losses in livestock and poultry production.
This research is responsible for investigating bovine mastitis, tuberculosis and paratuberculosis, ocular diseases including infectious bovine keratoconjunctivitis (pinkeye) and ultraviolet irradiation, brucellosis, leptospirosis, and reproductive diseases; contagious equine metritis; swine erysipelas, dysentery, streptococcal lymphadenitis, and mycobacteriosis; fowl cholera of chickens and turkeys, and turkey airsacculitis. Investigations of mycoses and mycotoxicoses include studies in swine, cattle and poultry. The research of this laboratory is included in 23 intramural CRIS units and 22 extramural cooperative and 4 PL-480 agreements, in addition to informal collaborative studies.

Senior scientific staff from the Laboratory make additional contributions to the scientific community through teaching, lecturing, acting as graduate advisors, participating on specialty boards and on national and international committees involved with their specific area of expertise.

\section{BOVINE MASTITIS}

RW Brown, DVM, PhD, Dip1 ACVM

JS McDonald, DVM, PhD, Dipl ACVM

MN Mickelson, PhD

AJ Anderson, Technician

JW Moran (NRC Postdoctoral Fellow)

Cows vary in susceptibility to intramammary infections and the development of mastitis. NADC studies are involved in defining the factors that cause these differences to develop methods for enhancing the cow's resistance. Previous studies show that glands with wide teat canals, as determined by radiography, are more susceptible to infections and that there is a progressive dilation of the teat canal with age. Present lines of research are concerned with (1) defining the susceptibility of the udder to new infections during the nonlactating period by injecting strains of streptococci, staphylococci, and coliforms into the mammary gland through the teat canal at various intervals of the dry period; 


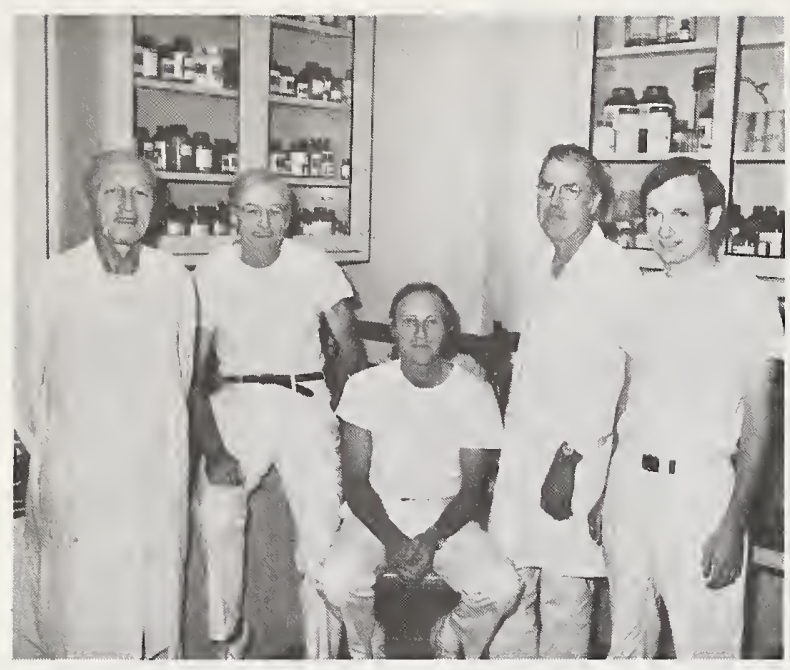

M. N. Mickelson, R. W. Brown, A. J. Anderson, J. S. McDonald, J. W. Moran (left to right)

(2) identifying the compounds in milk that affect the growth of Streptococcus agalactiae and determining their mode of action; and (3) examining the lactoperoxidase-thiocyanatehydrogen peroxide inhibitory system in milk and the mechanisms by which it may inhibit the growth of $\underline{S}$.

agalactiae and other organisms such as substrate transport. L-cystine, which is present in milk, was found to stimulate the growth of $\underline{S}$. agalactiae by counteracting the lactoperoxidase system. Concentrating the compound was found to increase during the early dry period and may account for the increase in susceptibility to infection with S. agalactiae. Isolating and identifying other compounds in milk that act in a similar manner are being pursued. The mechanism by which L-isoleucine and other branch-chained amino acids inhibit the growth of $\underline{S}$. agalactiae in milk is also being investigated. An understanding of the nutritive properties of milk for pathogenic organisms may provide the fundamental information necessary for future research on influencing a cow's resistance to mastitis by altering the concentration of specifically active compounds in milk through the $\operatorname{cow}^{\circ} \mathrm{s}$ diet.

\section{Key Publications}

Brown RW, Baetz AL. Separation from whey of three growth factors for Streptococcus agalactiae. Am J Vet Res 37:75-78. 1976.

McDonald JS. Radiographic method for anatomic study of the teat canal: characteristics related to resistance to new intramammary infection during lactation and the early dry period. Cornel1 Vet 65:492-499. 1975.

Mickelson MN. Glucose transport in Streptococcus agalactiae and its inhibition by lactoperoxidasethiocyanate-hydrogen peroxide. $\mathrm{J}$ Bacteriol 132:541-548. 1977.

\section{Current Publications}

Brown RW, Scherer RK. Classification of Staphylococcus epidermidis and Micrococcua strains isolated from bovine milk. Am J Vet Res 39: 767-772. 1978.

Brown RW, Thomas JL, Cook HM, Riley JL, Booth GD. Effect of environmental temperature stress on intramammary infections of dairy cows and monitoring of body and intramammary temperatures by radiotelemetry. Am J Vet Res 38: 181-187. 1977.

McDonald JS, McDonald TJ, Anderson AJ. Antimicrobial sensitivity of aerobic gram-negative rods isolated from bovine udder infections. Am J Vet Res 38: 1503-1507. 1977.

McDonald JS. Streptococcal and staphylococcal mastitis. J Am Vet Med Assoc 170:1157-1159. 1977.

Mickelson MN. Glucose transport in Streptococcus agalactiae and its inhibition by lactoperosidasethiocyanate-hydrogen peroxide. J Bacteriol 132:541-548. 1977. 


\section{BOVINE BRUCELLOSIS}

\section{Staff:}

BL Deyoe, DVM, PhD

TA Dorsey, DVM

JB Patterson, BS

M Phillips, PhD

LB Tabatabai, PhD

LA Garrett, BS

KB Meredith, Technician

Investigations in this project are directed toward developing methods and knowledge that will benefit improved control of and eliminate brucellosis in cattle and swine. Current specific objectives are ( 1 ) evaluating immunogenicity and postvaccinal responses of cattle of various ages to reduced dosages of live strain 19 vaccine, thereby seeking to improve and expand use of currently available vaccine;

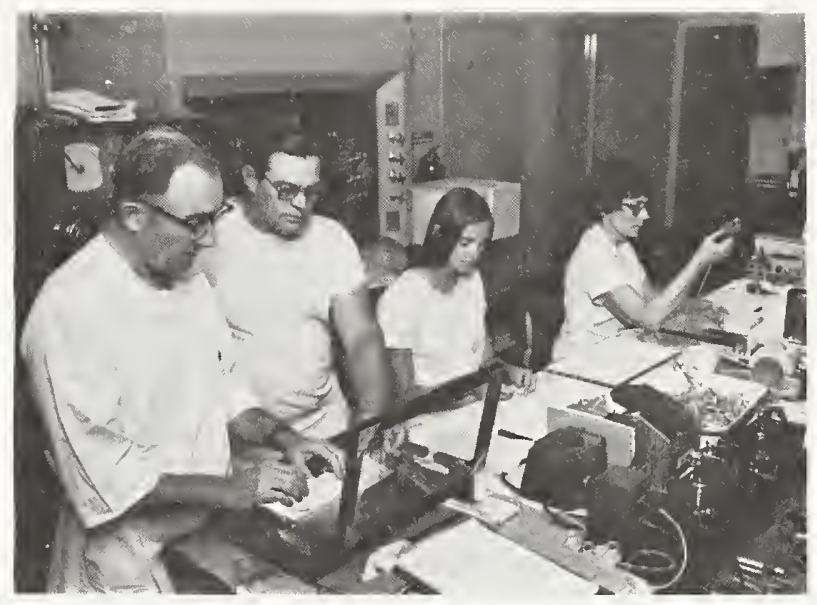

T. A. Dorsey, B. L. Deyoe, L. A. Garrett, K. M. Meredith (clockwise)

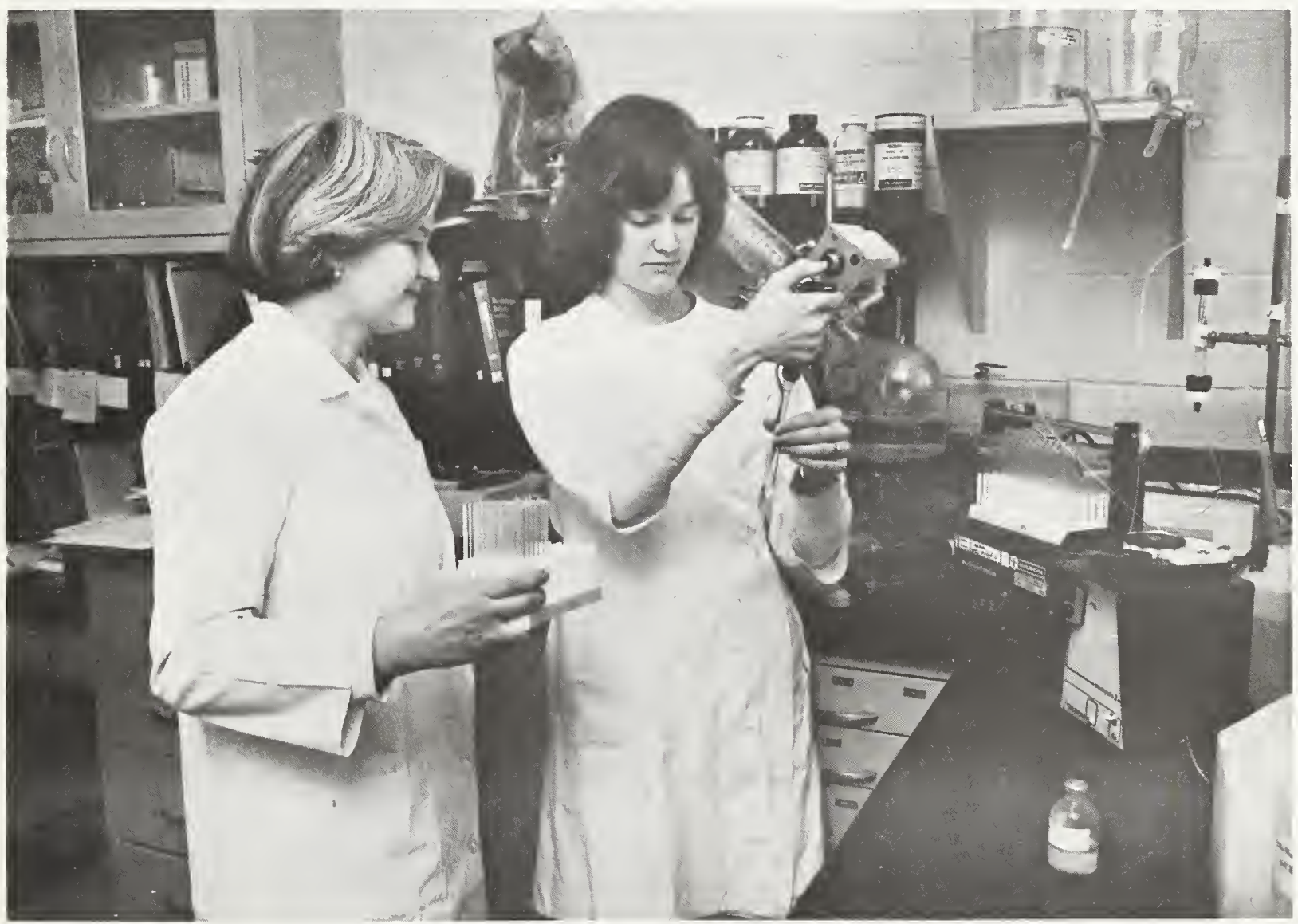

L. B. Tabatabai, L. Schmidt (left to right) 
(2) fractionating, isolating, and characterizing antigenic components of Brucella abortus to improve diagnostic methods by developing more specific test systems; (3) developing an effective nonviable cell-fraction vaccine for use where live vaccine is contraindicated; and (4) identifying and characterizing nonlipopolysaccharide toxins of $B$. abortus to develop greater knowledge of the pathogenesis of the disease. This project also has cooperative agreements with 14 universities active in working on various aspects of brucellosis.
Current Publications

Deyoe BL. Brucellosis research in progress in the United States. Proc Livestock Conservation Inst $62: 68-70.1978$.

Patterson JM, Deyoe BL. Effect of physical properties of milk fat globules on Brucella ring test sensitivity. J Dairy Sci 60:851856. 1977.

Tabatabai LB, Deyoe BL, Stone SS. Isolation and characterization of a toxic protein-rich fraction from Brucella abortus. Fed Proc 37: 182. 1978.

\section{REPRODUCTIVE DISEASES OF CATTLE}

\section{Staff :}

DE Hughes, DVM, MS, Dip1 ACVM

OH Stalheim, DVM, PhD

JH Bryner, PhD

JW Foley, Technician

ME Eimers, BS

This research is in progress in three areas (1) maternal and fetal responses to infections of the bovine genital tract, (2) effects of mycoplasmas, and (3) bacterial infections on bovine reproduction. The first looks for new causes of abortion and infertility in cattle, such as sarcocystis and toxoplasmosis, and is concerned with the newly recognized venereal disease of horses known as contagious equine metritis. The results indicate that sarcocystis may be a significant part of current losses, and epidemiology studies are under way.

Mycoplasmas are smaller than bacteria and lack cell walls. They are common inhabitants of the bovine genital tract. Although they can cause reproductive diseases in cows and bulls, how much and under what cir- cumstances remains to be defined. The ureaplasmas and spiroplasmas are related organisms whose disease potential is under study.

Research is in progress to improve sampling and culturing techniques for diagnosing Campylobacter fetus infection in cattle. Methods currently on trial include collecting samples from infected animals at the

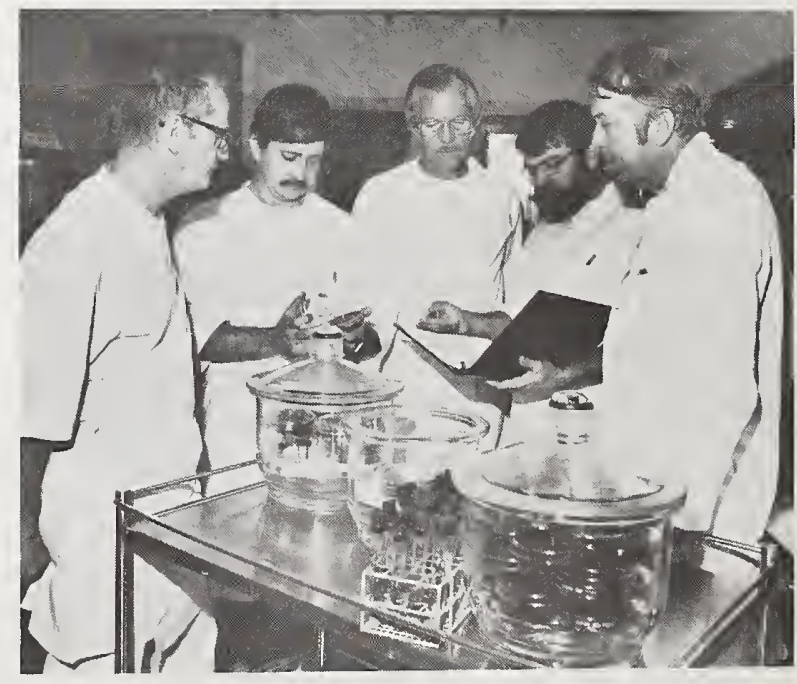

D. E. Hughes, M. E. Eimers, J. H. Bryner, J. W. Foley, O.H.V. Stalheim (clockwise) 
farm, inoculating selective-enrichment transport mediums, incubating the cultures in the laboratory, and identifying the pathogenic bacterium in the culture by direct and indirect immunofluorescent microscopy, immunoelectron microscopy, and biochemical testing. Other studies involve improving campylobacter bacterins through testing for optimum antigenic quality and quantity and adjuvants using a pregnant guinea pig protection test and correlating this test in cattle. Another study area involves determining the relatedness of $\underline{C}$. fetus isolants from animals with isolants from cases of the human disease for epidemiologic purposes. Bacteriophage testing correlated with serology is used to determine relatedness of strains.

\section{Current Publications}

Barnett D, Carter JKY, Hughes DE, Baetz AL, Fayer R. Practicable diagnosis of acute bovine sarcocystosis causally related to bovine abortion. Proc 20th Ann Mtg Am Assoc Vet Lab Diag 131-138. 1977.

Bokkenheuser F, Richardson MJ, Bryner JH, Ziegenfuss R. Enteric Campylobacter infection in small children. 78th Ann Mtg Am Soc Microbiol Abstr C-62. 1978.

Bryner JH, Foley JW, Hubbert WT, Matthews PJ. Pregnant guinea pig model for testing efficacy of Campylobacter fetus vaccines. Am $\mathrm{J}$ Vet Res 39:119-121. 1978.

Stalheim OHV. Introduction. In: Laboratory Diagnosis of Mycoplasmosis in Food Animals. OH Stalheim, ed. Proc Am Assoc Vet Lab Diag 6-11. 1977.

Stalheim OHV. Bovine leptospirosis. In: Great Plains Beef Cow-Calf Handbook. Cooperative Extension Service, Great Plains States (1977): 3155.1-3155.3. 1977.

Stalheim OH. Report of Committee on Mycoplasmosis. Am Assoc Vet Lab Diag Newsletter 7. 1978.

Stalheim OHV, Gallagher, JE. Ureaplasmal epithelial lesions related to ammonia. Infect Immun 15:995-996. 1977.

Stalheim OHV, Hall EC. Adherance and adsorption of ureaplasmas to spermatozoa. 77th Ann Mtg Am Soc Microbiol Abstr 132. 1977.

Stalheim OH, Hubbert WT, Boothe AD et a1. Infectivity of Toxoplasma gondii for calves and pregnant cows. AVMA Mtg Abst 143:190. 1978.

Stalheim OHV, Stone SS, Blackburn BO, Foley J. Antibody response of horses to Mycoplasma mycoides subspecies capri. Am J Vet Res 39:1734-1737.

\section{LEPTOSPIROSIS OF CATTLE}

\section{Staff :}

HC E1linghausen, $\mathrm{PhD}$

CA Belzer, BS

AB Thiermann, DVM, PhD

Two areas of emphasis in the leptospirosis research project are studies of the agent and host interactive processes.

Before 1975, we directed our attention to developing (1) the basic nutrition of the leptospires, (2) their maintenance in the laboratory, (3) the preservation of their antigenic, immunogienic, and virulence properties, 


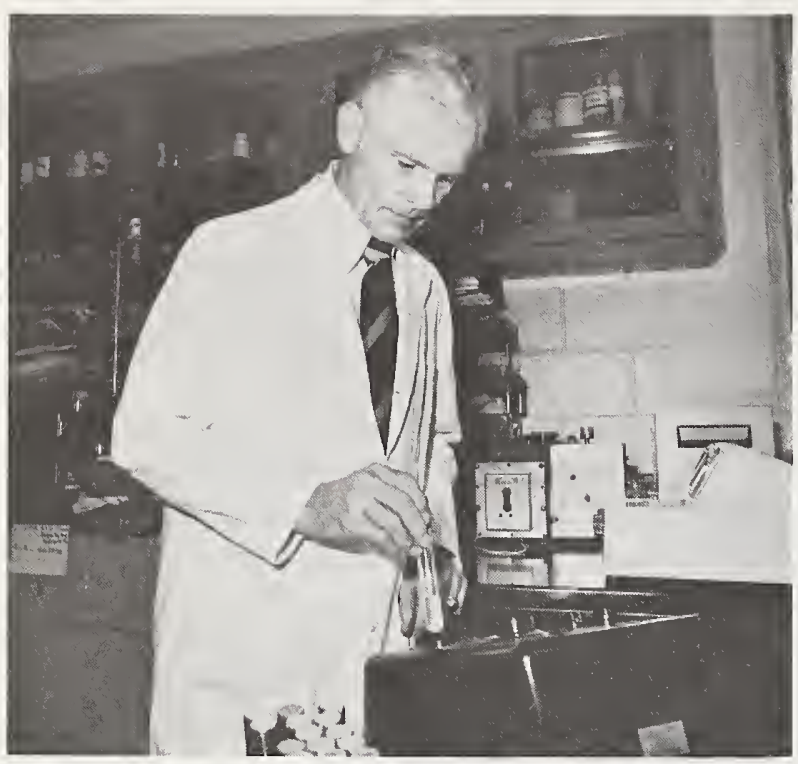

H. C. Ellinghausen

and (4) their lethal and infective characteristics for animals.

In 1975, we redirected our efforts because of an increasing need for information about the 37 member Hebdomadis serogroup. Characteristics of the immune response of cattle were determined for Leptospira hardjo, and it was determined that cattle consistently could be experimentally infected. Cross-agglutinating activity of these cattle sera and the early and late antibody response have been studied and reported. Remaining to be investigated with these materials were (1) the chronological development of protective antibodies, (2) the cross absorption of agglutinins, and (3) the distribution of IgM and IgG antibody. Cattle were inoculated with diverse groups of leptospires, and similar studies to those with L. hardjo are being carried out to gain a more complete picture of sero-reaction of cattle and the rapidity, duration, and nature of the immune response.

Another avenue of investigation involves developing procedures that

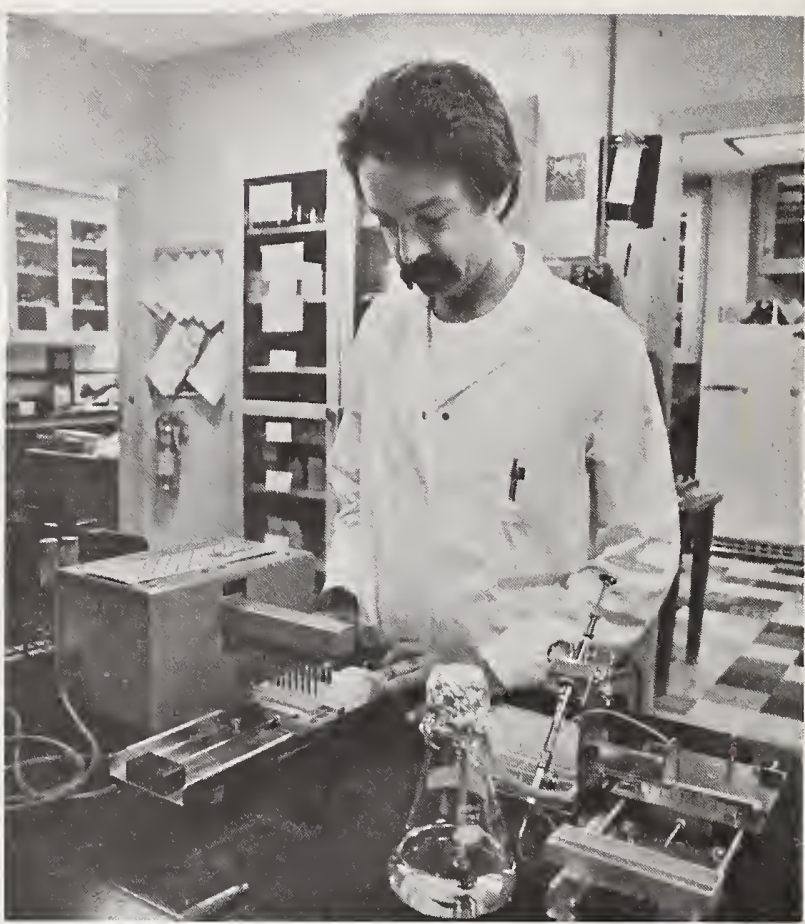

A. B. Thiermann

optimize conditions for isolating leptospires from bovine urine. Areas currently being investigated include (1) the role of urinary solutes in the toxicity of bovine urine for leptospires, (2) use of furosemide to obtain urinary samples to isolate leptospires, and (3) comparison of physical, biochemical, and immunological characteristics of bovine urine before and after experimental infection with serovar hardjo.

\section{Key Publications}

Ellinghausen HC, Painter GM. Growth, survival, antigenic stability, and virulence of Leptospira interrogans serotype canicola. J Med Microbiol 9:29-37. 1976.

Painter GM, Ellinghausen HC. Immunizing potency of Leptospira interrogans serotype canicola after heat inactivation and various temperatures. J Med Microbiol 9:487-492. 1976. 
Nervig RM, Ellinghausen HC, Cardella MA. Growth, virulence, and immunogenicity of Leptospira interrogans serotype szwajizak. Am J Vet Res 38:1421-1424. 1977.

\section{Current Publications}

Ellinghausen HC, Deyoe BL, Nervig RM. Leptospirosis in perspective. Proc U.S. Animal Health Assoc 8th Ann Mtg 161-182. 1977.
Nervig RM, Ellinghausen HC, Cardella MA. Growth, virulence, and immunogenicity of Leptospira interrogans serotype szwajizak. Am J Vet Res 38: 1421-1424. 1977.

Nervig RM, Ellinghausen HC. Viability of Leptospira interrogans serotype grippotyphosa in swine urine and blood. Corne11 Vet 68:70-77. 1977.
INFECTIOUS BOVINE KERATOCONJUNCTIVITIS (PINKEYE) OF CATTLE

\section{Staff:}

GW Pugh, Jr, DVM, PhD

KE Kopecky, DVM, MS

TJ McDonald, BS

VD Schultz, Technician

Infectious bovine keratoconjunctivitis (IBK), or "pinkeye," is a highly contagious disease of cattle caused by Moraxe1la bovis. Pinkeye is a major cattle disease causing economic loss through slower calf growth, slower weight gain in feeder cattle, reduced milk yields from dairy cattle, treatment costs, as well as eye disfigurement and sometimes blindness. The disease occurs perennially in all cattle-raising areas. It usually appears during the early summer, which is the time of both maximum solar ultraviolet radiation and maximum $\mathrm{fly}$ population. Both of these factors are important in the etiology of the disease.

The investigational approach to control IBK being pursued involves applying such immunologic techniques as the development and use of polyvalent vaccines, as well as highly immunogenic fractions and strains of M. bovis. Also, using passive immunity as a source of protection for young calves (the most susceptible age) is being studied by vaccinating pregnant cows to stimulate protective colostral antibodies to protect the neonatal calves from IBK and to eliminate the carrier state in the dam (a major source of new infection). Because different strains of $\underline{M}$. bovis differ in their antigenic character-

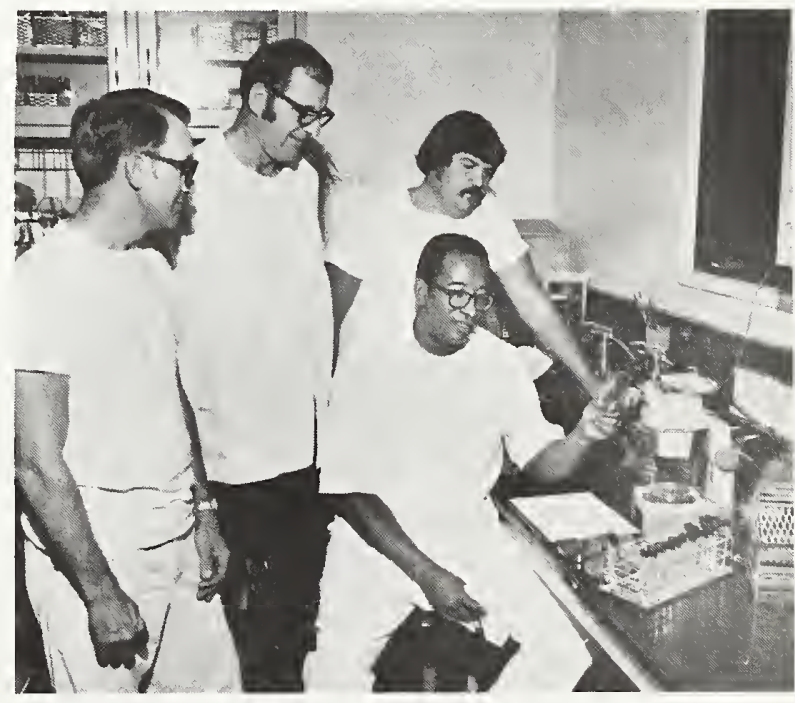

V. D. Schultz, K. E. Kopecky, T. J. McDonald, G. W. Pugh, Jr. (clockwise) 
istics, single strain vaccines might not be effective in protecting cattle herds where multiple strain infections are likely. This would necessitate using polyvalent vaccines or an immunogen that would give a broad range of cross reactivity (protection). Possibly, such an immunogen would be an adjuvanted surface fraction of $\underline{M}$. bovis. The fact that adjuvanted whole cells and surface fractions of $\underline{M}$. bovis were efficient inducers of an immune response with reduced doses supports our contention that this research area might offer a method of pinkeye control under certain conditions. Controlling IBK with antimicrobial agents is also being studied to determine whether $\underline{M}$. bovis can be eliminated from infected cattle (including carriers). Little is known about the carrier state at present; therefore, research in this area is of paramount importance.

Success in this research will lead to increased amounts of beef and dairy products and at the same time reduce the production cost. In this way, it will benefit the producer as well as the consumer.

\section{Key Publications}

Hughes DE, Pugh Jr GW, McDonald TJ. Radiation and Moraxella bovis in the etiology of bovine infectious keratoconjunctivitis. Am J Vet Res 26:1331-1338. 1965.

Pugh GW Jr, Hughes DE, McDonald TJ. The isolation and characterization of Moraxe11a bovis. Am J Vet Res 27: 957-962. 1966 .

Pugh GW Jr, Hughes DE, Booth GD. Experimentally induced infectious bovine keratoconjunctivitis: Effectiveness of a pilus vaccine against exposure to homologous strains of Moraxella bovis. Am $\mathrm{J}$ Vet Res 38:1519-1522. 1977 .

\section{Current Publications}

Hughes DE, Pugh Jr GW, Booth GD. Induced infectious bovine keratoconjunctivitis: Vaccination with whole cell bacterins of Moraxella bovis mixed with Freund's incomplete adjuvant. Am J Vet Res 38:1905-1907. 1977.

Kopecky KE. Ozone depletion: Implication to the veterinarian. $\mathrm{J}$ Am Vet Med Assoc 173:729-733. 1978.

Pugh GW Jr, Hughes DE, Kohlmeier, RH, Wallace JR, Graham CK. Infectious bovine keratoconjunctivitis: Comparison of a fluorescent antibody technique and cultural isolation for the detection of Moraxella bovis in eye secretions. Am J Vet Res 38: 1349-1352. 1977.

Pugh GW Jr, Hughes DE, Booth GD. Experimentally induced infectious bovine keratoconjunctivitis: Effectiveness of a pilus vaccine against exposure to homologous strains of Moraxella bovis. Am J Vet Res 38:1519-1522. 1977.

Pugh GW Jr, Hughes DE, Booth GD. Serologic response of vaccinated cattle to strains of Moraxella bovis isolated during epizootics of keratoconjunctivitis. Am J Vet Res $39: 55-57.1978$.

Pugh GW Jr, McDonald TJ. Infectious bovine keratoconjunctivitis: Treatment of Moraxella bovis infections with antibiotics. US An HIth Assoc 80th Ann Mtg 1977:120-130. 1978.

Pugh GW Jr, McDonald $\mathrm{TJ}$, Larsen $\mathrm{AB}$. Experimentally induced infectious bovine keratoconjunctivitis: Potentiation of a Moraxella bovis pilus vaccine's immunogenicity by vaccination with Mycobacterium paratuberculosis bacterin. Am J Vet Res 39(10):1656-1661. 1978. 
Staff :

AB Larsen, DVM, MS

RS Merkal, PhD

AM Hintz, MS

DL Whipple, BS

Methods are being studied to immune cattle against paratuberculosis with nonliving vaccines. They include determining size of dose, age, vaccinating, and proper adjuvant. Both virulent and nonvirulent strains of Mycobacterium paratuberculosis are being evaluated. Procedures for determining the efficacy and potency of the vaccines before they leave the laboratory are being developed.

Hamsters and lemmings are being investigated to determine if either of these species can be used for evaluating the immunizing agents.

The effect of chemotherapeutics on $\underline{M}$. paratuberculosis in vitro is being evaluated by two measurements (1) incorporating $3 \mathrm{H}$-uracil into $\mathrm{RNA}$ and (2) colony counts following diffusion through agar. Chemotherapeutics exhibiting adverse effects on the organism in vitro will be evaluated in orally-infected hamsters.

The serologic identification of paratuberculous cattle will be examined employing protoplasmic fractions as antigens, in gel diffusion precipitin, and counterimmunoelectrophoretic precipitin tests.

Iron chelators, such as mycobactins and nocobactins, of mycobacteria and related genera, will continue to be isolated and characterized in an effort to develop species-specific antimicrobial compounds.

\section{Key Publications}

Larsen AB, Moyle AI, Himes EM. Experimental vaccination of cattle

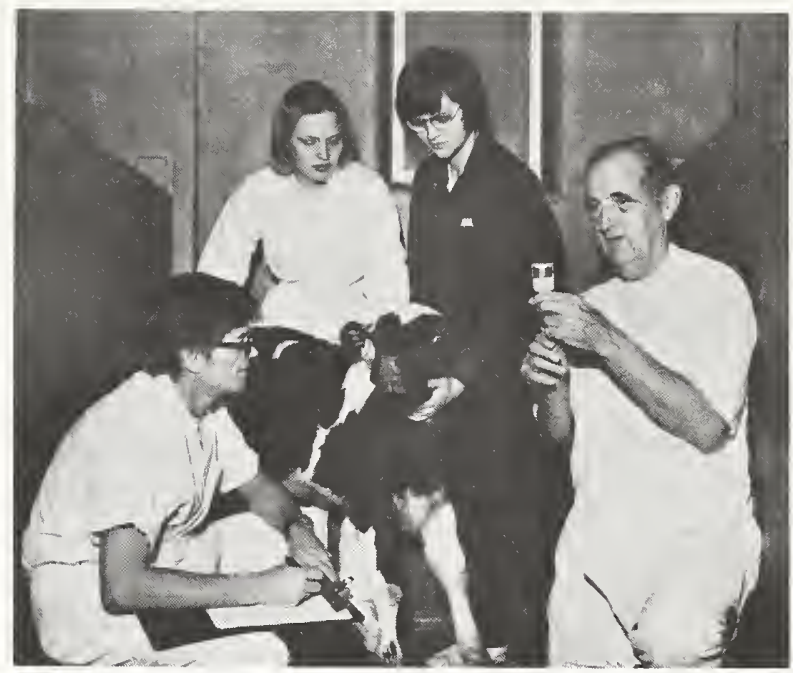

R. S. Merkal, A. M. Hintz, D. L. Whipple, A. B. Larsen (clockwise)

against paratuberculosis (Johne's disease) with killed bacterial vaccines: A controlled field study. Am J Vet Res 39:65-69. 1978.

Larsen AB, Miller JM, Merkal RS. Subcutaneous exposure of calves to Mycobacterium paratuberculosis compared with intravenous and oral exposures. Am J Vet Res 38:1669-1671. 1977.

\section{Current Publications}

Buergelt CD, Delisle G, Hall CE, Merkal RS, Duncan JR. In vitro lymphocyte transformation as a herd survey method for bovine paratuberculosis. Am J Vet Res 39: 591-596. 1978 .

Buergelt CD, Hall CE, Merkal RS, Whitlock RH, Duncan JR. Lymphocyte transformation: An aid in the diagnosis of paratuberculosis. Am J Vet Res 38:1709-1715. 1977.

Johnson DW, Muscoplat CC, Larsen $A B$, Thoen CO. Skin testing, fecal culture, and lymphocyte immunostimulation in cattle inoculated with Mycobacterium paratuberculosis. Am J Vet Res 38: 2023-2025. 1977. 
disease) with killed bacterial

vaccines: A controlled field study.

Am J Vet Res 39:65-69. 1978.
Larsen $A B$, Moyle AI, Himes EM. Experimental vaccination of cattle against paratuberculosis (Johne's

\section{MYCOBACTERIOSIS OF SWINE}

\section{Staff:}

AB Larsen, DVM, MS

RS Merkal, $\mathrm{PhD}$

AM Hintz, MS

DL Whipple, Technician

Epizootiological studies are being made of swine herds affected with mycobacteriosis to determine the cause and the environmental sources of infection. Studies are in progress to develop measures for eliminating the disease on affected premises.

Because most tuberculosis found in swine is caused by the Mycobacterium avium complex, the effect of chemotherapeutics on $\underline{M}$. avium in vitro is being evaluated. Two measurements are being used (1) incorporating 3Huracil into RNA and (2) colony counts following diffusion through agar. Chemotherapeutics exhibiting adverse effects on the organism in vitro will be evaluated in artificially infected laboratory animals.

The time-temperature treatments of meat products needed to destroy the tubercle bacilli (‥ avium complex, which occur in swine, will be determined. This includes the production of weiners and other luncheon meats spiked with laboratory cultured organisms and with lesions obtained from swine at slaughter. These products are processed following varying protocols, then examined culturally for the numbers of organisms destroyed.

\section{SWINE ERYSIPELAS}

\section{Staff:}

RL Wood, DVM, PhD

DR Haubrich, BS

This project is concerned with investigations of epizootiology and pathogenesis of swine erysipelas. Studies have been made to determine the role of carrier swine and factors of external environment in maintenance and spread of the causative organism, Erysipelothrix rhusiopathiae. Current studies are concerned with serotype specificity in immunity of swine to the organism. Specific lack of immunity of vaccinated swine to certain strains of E. rhusiopathiae is being investigated. Statistical studies are being conducted in mice to

determine whether there is evidence that the refractory response of

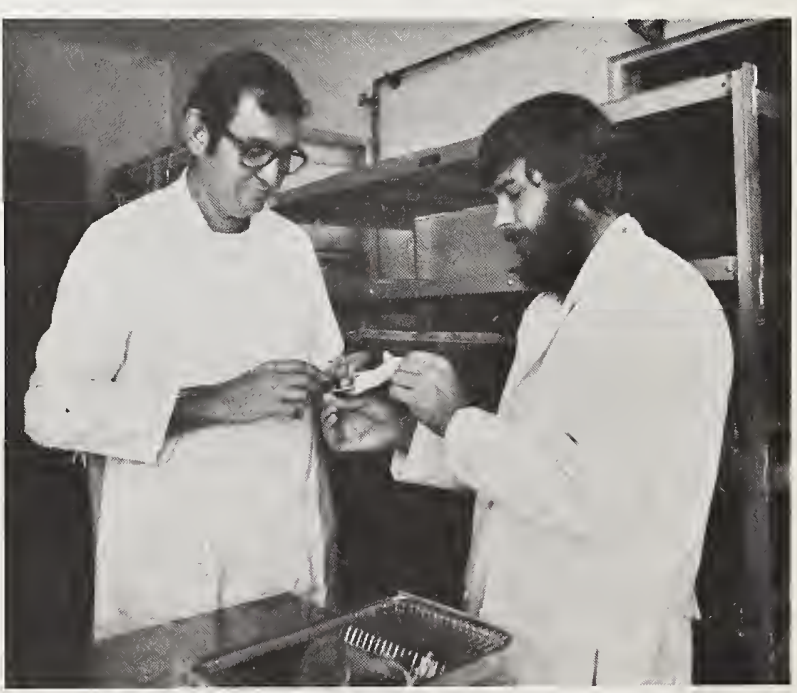

R. L. Wood, D. R. Haubrich (left to right) 
certain strains of the organism to immunity induced by standard erysipelas vaccine is related to their serotypes. New serotypes of the organism are being characterized, and studies to determine their stability are being made. Using the refractory strains as tools to provide comparison with more conventional strains of the organism, studies will be made to investigate the role of cell-mediated immunity in swine erysipelas.

\section{Key Publications}

Wood RL. Isolation of pathogenic Erysipelothrix rhusiopathiae from feces of apparently healthy swine. Am J Vet Res 35(1):41-43. 1974.
Wood RL. Specificity in response of immunized swine to challenge with different serotype strains of Erysipelothrix rhusiopathiae. Proc

Intl Pig Vet Soc, 4th Int Congress Q7. 1976.

\section{Current Publications}

Wood RL, Harrington $\mathrm{R} \mathrm{Jr}$.

Serotypes of Erysipelothrix rhusiopathiae isolated from swine and from soil and manure of swine pens in the United States. Am J Vet Res 39:18331840. 1978.

Wood RL, Haubrich DR, Harrington $\mathrm{R} J$ r. Isolation of previously unreported serotypes of Erysipelothrix rhusiopathiae from swine. Am J Vet Res 39: 1958-1961. 1978.
STREPTOCOCCIC LYMPHADENITIS OF SWINE (JOWL ABSCESSES)

\section{Staff:}

RL Wood, DVM, PhD

GE Wessman, PhD

NA Nord, Technician

Investigations in this project focus mainly on studies of antigens of group E Streptococci (GES) that cause streptococcic lymphadenitis of swine. The objective is to identify and characterize those antigens possessing important determinants of virulence and immunogenicity. The ultimate aim is to incorporate such an antigen(s) into diagnostic tests or into vaccines. Because group and type antigens have not been demonstrated to be of immunogenic or pathogenic significance, recent investigations have emphasized studies on an M-like protein antigen. This antigen is produced when GES are cultured in media supplemented with serum; the appearance of the antigen correlates with the development of resistance to phagocytosis by the GES. Antibodies to this antiphagocytic factor can be detected in hyperimmune and immune swine serums by means of bactericidal or long-chain tests. Attempts to isolate and purify this antigen are being made.

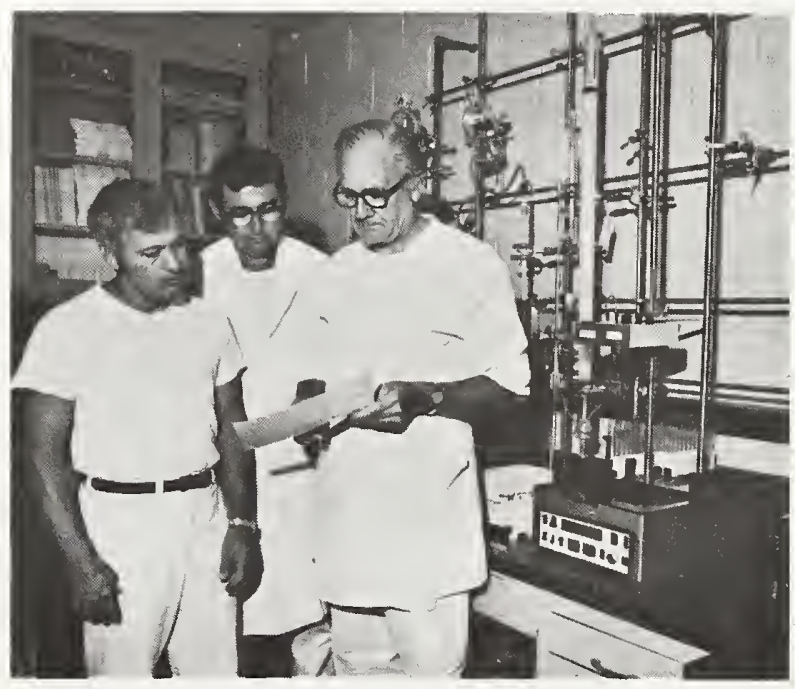

N. A. Nord, R. L. Wood, G. E. Wessman (clockwise) 
Immunization studies are being conducted involving swine given GES cellular extracts containing M-like protein to determine whether protection against the disease is conferred. Immunizing swine with concentrated whole-culture $\mathrm{Al}(\mathrm{OH})_{3-}$ adsorbate bacterins is also being attempted, with challenge provided by contact exposure to carrier swine.
Type antigens of the three recognized serotypes of GES are being further identified and characterized.

\section{Current Publication}

Wessman GE, Wood RL, Nord N. Detection of antibody to the antiphagocytic factor produced by group E streptococci. Cornell Vet 67:81-91. 1977.

\section{SWINE DYSENTERY}

\section{Staff:}

LA Joens, $\mathrm{PhD}$

DH Baum, MS

Basically, three areas of research are included in this project (1) serodiagnosis of swine dysentery, (2) examining the predisposing factors leading to the disease, and (3) developing an immunizing program against the disease. Recent work in serodiagnosis of the disease has led to the development of a microtitration agglutination test that uses inactivated Treponema hyodysenteriae antigen and enables researchers to measure agglutinins in swine serum macroscopically. This test appears to be specific for antibody to the pathogenic isolates of T. hyodysenteriae and demonstrates a significant level of antibody in convalescent pigs up to 10 to 11 weeks postinfection.

Pig immunity to swine dysentery has been examined through convalescent swine models. Our studies have shown that reexposed pigs, as long as 17 to 18 weeks postinfection, were resistant to rechallenge. Agglutinating antibody specific for $\underline{T}$. hyodysenteriae was demonstrated in colonic washings of reexposed pigs; fractionating one colonic washing sample demonstrated the antibody activity in the IgG fraction.
Future investigations will include more work on local antibody produced in both the convalescent and hyperimmunized pig to $\mathrm{T}$. hyodysenteriae. Isolating membrane-associated complexes to $\underline{T}$. hyodysenteriae will also be examined, along with the role that these complexes have in expressing the organism's pathogenicity.

\section{Key Publications}

Joens LA, Harris DL, Kinyon JM, Kaeberle ML. Microtitration agglutination for detection of Treponema hyodysenteriae antibody. J Clin Microbiol 8(3): 1978.

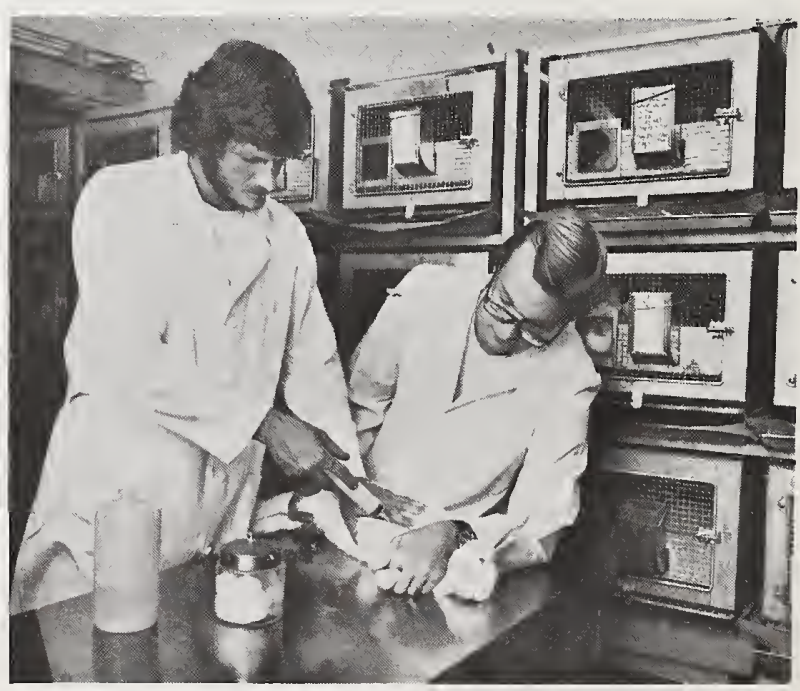

L. A. Joens, D. H. Baum (left to right) 
Current Publications

Joens LA, Kinyon JM, Baum DH, Harris DL. Immunofluorescent studies on Treponema hyodysenteriae. Proc Int 1 Pig Vet Soc Congress 4:C6. 1978.

Ritchie AE, Robinson IM, Joens LA, Kinyon JM. A bacteriophage for Treponema hyodysenteriae. Vet Rec 102:34-35. 1978.
Joens LA, Harris DL, Kinyon JM, Kaeberle ML. Microtitration agglutination for detection of Treponema hyodysenteriae antibody. J C1in Microbiol 8(3):293-298. 1978.

Joens LA, Songer JG, Harris DL, Glock RD. Experimental infection with Treponema hyodysenteriae in guinea pigs. Infect Immun 22(1):132-135. 1978.

\section{MYCOSES AND MYCOTOXISES}

\section{Staff:}

AC Pier, DVM, PhD, Dipl ACVM

JL Richard, PhD

JR Thurston, PhD

RE Fichtner, BS

CD Anderson, Technician

Two major types of diseases caused by fungal agents are being investigated: the mucoses and the mycotoxicoses. The mycoses are fungal infections that invade, multiply, and grow fungal pathogens in host tissues. Asper-

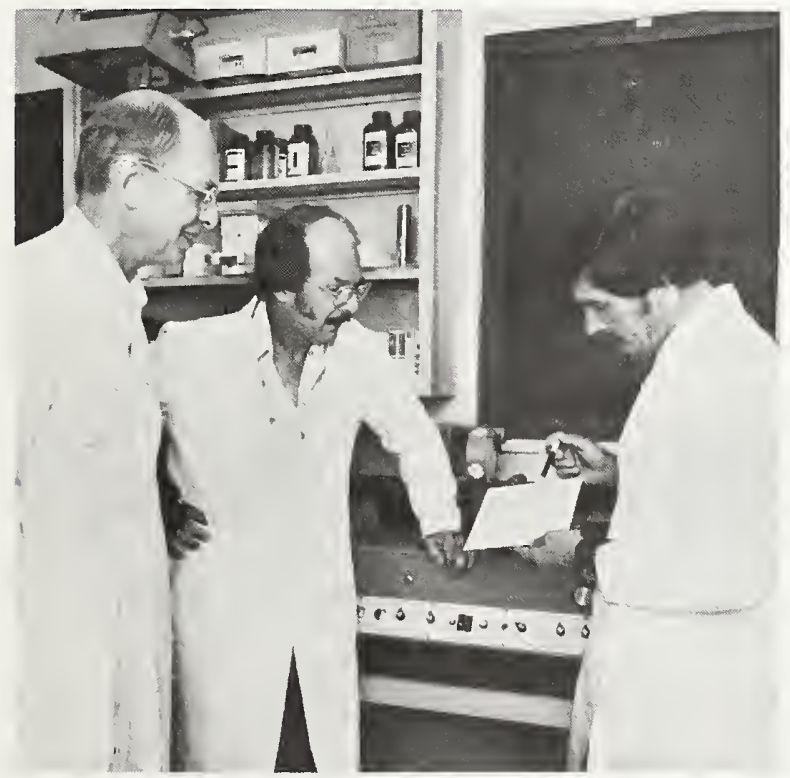

J. R. Thurston, A. C. Pier, J. L. Richard (clockwise) gillosis is the mycosis causing the greatest economic loss in livestock and poultry. Research in our mycology unit on aspergillosis emphasizes elucidating the pathogenesis of mycotic abortion in ruminants caused by Aspergillus fumigatus and studying respiratory aspergillosis in poultry and rabbits caused by $\underline{A}$. fumigatus and other aspergilli. Reproducible oral and aerosol exposure techniques are used for livestock, poultry, and laboratory animals. Serologic tests for antibodies to A. fumigatus have been devised and correlated with

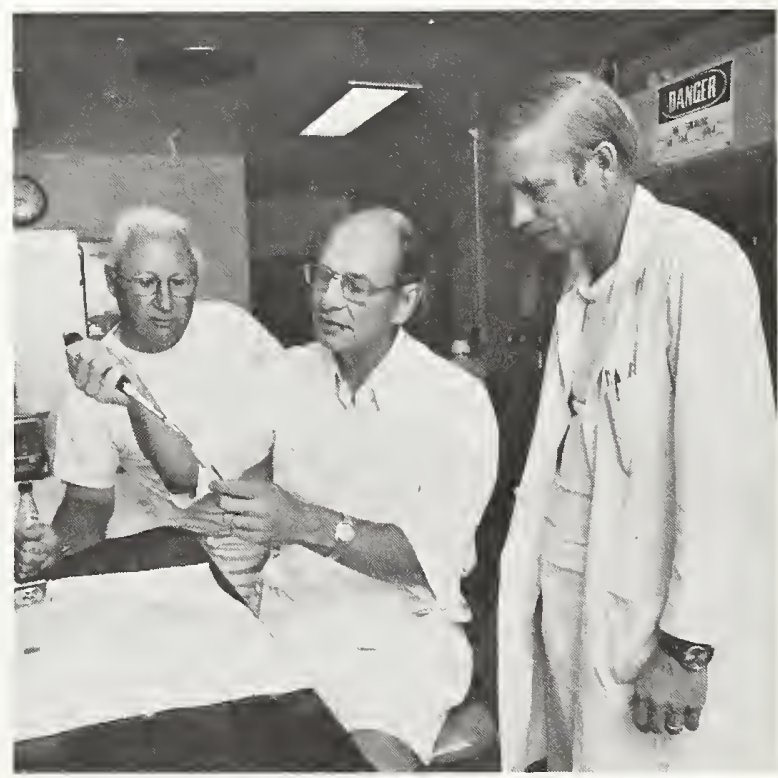

C. D. Anderson, J. R. Thurston, R. E. Fichtner (clockwise) 
development of lesions and disease states to facilitate diagnosis. Current studies of aspergillosis immunity are in progress. Other mycoses studies in our unit include nocardiosis and dermatophilosis, and developing diagnostic methods is the primary objective.

The mycotoxicoses represent a newly recognized and important area of interest in veterinary medicine. The mycotoxins are metabolites of certain fungi that grow on animal feeds. These metabolites cause acute and chronic disease processes of substantial economic importance. In addition to overt clinical disease, we have shown that some mycotoxins reduce the growth rate of swine, cattle and poultry; impair immunogenesis; and lower native resistance to some infections. These latter effects may occur at levels of toxin intake below those causing overt clinical disease. Our current research emphasis on mycotoxins is to determine the biological effects of consumption of selected toxins in poultry, swine, and cattle. Toxins receiving major emphasis include aflatoxin, ochratoxin $\mathrm{A}$, penitrem $\mathrm{A}$, and $\mathrm{T}-2$ toxin. These and other mycotoxins are sought in specific disease episodes in commercial herds and flocks.

\section{Key Publications}

Pier AC, Fichtner RE, Cysewski SJ. Effects of aflatoxin in the cellular immune system. Ann Nutr Aliment 31:781-788. 1977.

Richard JL, Thurston JR. Effect of aflatoxin on phagocytosis of

Aspergillus fumigatus spores by rabbit alveolar macrophages. App1 Microbio1 $30: 4447.1977$.

\section{Current Publications}

Cysewski SJ. Mycotoxins in animal production. Proc 1977 Maryland Nutrition Conf for Feed Manufacturers 15-20. 1977.

Cysewski SJ. The chemistry of the tremorgenic mycotoxins. In: Mycotoxic Fungi, Mycotoxins and Mycotoxicoses: An encyclopedic Handbook. TD Wy1lie and LG Morehouse, eds. Marcell Dekker, Inc, New York, NY. 357-364. 1977.

Cysewski SJ. The effects of tremorgenic mycotoxins on laboratory

animals. In: Mycotoxicoses of Domestic and Laboratory Animals, Poultry, and Aquatic Invertebrates and Vertebrates. TD Wyllie and LG Morehouse eds. Marcel Dekker, Inc, New York, NY. 472-477. 1977.

Cysewski SJ. The effects of tremorgenic mycotoxins in cattle. In: Mycotoxicoses of Domestic and Laboratory Animals, Poultry and Aquatic Invertebrates. TD Wyllie and LG Morehouse, eds. Marcel Dekker, Inc, New York, NY. 142-144. 1977.

Cysewski SJ, Wood RL, Pier AC, Baetz AL. The effects of aflatoxin on the development of immunity to swine erysipelas. Am J Vet Res 39:445-448. 1978.

Engstrom GW, Richard JL, Cysewski SJ. High-pressure liquid chromatographic method for detection and resolution of rubratoxin, aflatoxin, and other mycotoxins. Agr and Food Chem 25: 833-836. 1977

Pier AC. Biological effects and diagnostic problems of mycotoxicoses in poultry. Proc 1lth Natl Mtg on Poultry Health and Condemnations. Oct 19-20, 1976, Delmar, MD 1-10. 1977.

Pier AC. An assessment of needs in mycotoxin research. Mycopathologia 65:47-49. 1978 . 
Pier AC, Cysewski SJ, Richard JL, Baetz AL. Experimental mycotoxicoses in cattle with aflatoxin, ochratoxin, rubratoxin, and T-2 toxin. Proc 20th World Vet Congr Thessaloniki, Greece, July 6-12, 1975. 2:1284-1285. 1977.

Pier AC, Cysewski SJ, Richard JL, Thurston JR. Mycotoxins as a veterinary problem. Proc US-Japan Congr on Mycotoxins. Toxicon, J Rodricks, ed. 745-750. 1977.

Pier AC, Cysewski SJ, Richard JL, Baetz AL, Mitchel1 L. Experimental mycotoxicoses in calves with aflatoxin, ochratoxin, rubratoxin, and $\mathrm{T}-2$ toxin. Proc 80th Ann Mtg US Anim H1th Assoc 1976:130-148. 1977.

Pier AC, Fichtner RE, Cysewski SJ. Effects of aflatoxin in the cellular immune system. Ann Nutr Alim 31: 781788. 1977.

Pier AC, Richard JL, Thurston JR. The influence of mycotoxins on resistance and immunity. Proc Symp on the interaction of Mycotoxins in Animal Production, Natl Acad Sci 56-66. 1978.
Pier AC, Thurston JR, Richard JL, Cysewski SJ. Mode of action of aflatoxin on resistance and immunity. Proc 2nd Intl Symp on Mycotoxins (IUPAC), Pulawy, Poland, 1974. (Published: Zeszyty Problemowe Postepow Nauk Rolniczych 189:157161. 1977).

Richard JL, Cysewski SJ, Pier AC, Booth GD. Comparison of effects of dietary T-2 toxin on growth, immunogenic organs, antibody formation, and pathologic changes in turkeys and chickens. Am J Vet Res 39:16741679. 1978.

Richard JL, Thurston JR, Pier AC. Effects of mycotoxins on immunity. In: Toxins: Animal, Plant and Microbial, Proc 5th Int1 Symp, $P$ Rosenberg, ed. Pergamon Press, NY. 801-817. 1978.

Richard JL, Thurston JR, Lillehoj EB, Cysewski SJ, Booth GD. Complement activity, serum protein, and liver changes in guinea pigs given sterigmatocystin or aflatoxin alone or in combination. Am J Vet Res 39(1):163166. 1978.
PASTEURELLOSIS (FOWL CHOLERA)

\section{Staff:}

KR Rhoades, DVM, PhD

RB Rimler, PhD

KA Brogden, MS

WE Brown, BS

Research on fowl cholera is currently directed toward preventing disease by improving vaccine effectiveness and serotyping techniques.

Efforts to improve vaccines include (1) studying the effectiveness of vaccines prepared from specific immunotypes of Pasteure11a multocida, cultivated in a variety of environments, for inducing protection against challenge with either homologous or heterologous immunotypes; and (20 studying various components of $\underline{P}$. multocida to determine their biochemical nature, antigenicity, immunogenicity, and toxicity to gain knowledge of the role of these components both as protective antigens and as contributors to pathogenicity.

Efforts to improve serotyping techniques are concerned with improving the gel-diffusion-precipitin test. Studies are under way to improve specificity and sensitivity of the 


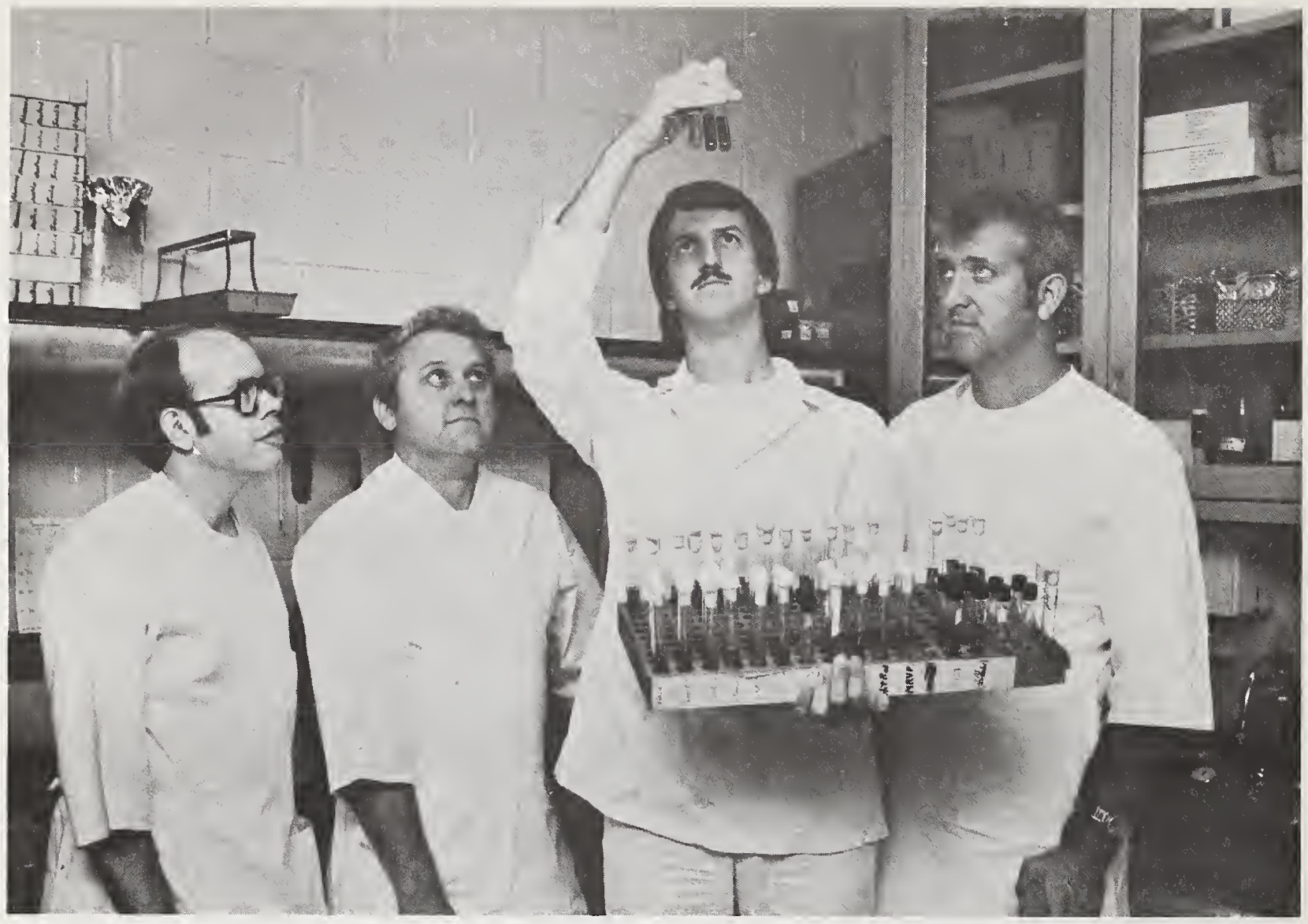

W. E. Brown, K. R. Rhoades, K. A. Brogden, R. B. Rimler (left to right)

typing antigens and serums. We use this test to evaluate large numbers of field isolates to determine the distribution of serotypes and to search for additional serotypes.

\section{Key Publications}

Heddleston KL, Rebers PA. Fowl cholera: Cross-immunity induced in turkeys with formalin-killed in-vivopropagated Pasteurella multocida. Avian Dis 16: 578-586. 1972.

Heddleston KL, Gallagher JE, Rebers PA. Fowl cholera: Gel diffusion precipitin test for serotyping Pasteure1la multocida from avian species. Avian Dis 16:925-936. 1972.
Current Publications

Brogden KA, Rebers PA. Serological examination of the Westphal-type 1ipopolysaccharides of Pasteurella multocida. Am J Vet Res 39:16801682.1978.

Brogden KA, Rhoades KR, Heddleston KL. A new serotype of Pasteurella multocida associated with fowl cholera. Avian Dis 22:185-190. 1978.

Heddleston KL, Rhoades, KR. Avian pasteurellosis. In: Diseases of Poultry. MS Hofstad, BW Calnek, CF Helmboldt, WM Reid and HW Yoder Jr, eds. Iowa State University Press, Ames, IA pp 181-207. 1978. 
Phillips M, Rebers PA. Isopycnic characterization of lipopolysaccharides from Pasteurella multocida. Analytical Biochem 85: 265-270. 1978.

Rebers PA, Heddleston KL. Fowl cholera: Induction of cross-protection in turkeys with bacterins prepared from hostpassaged Pasteurella multocida. Avian Dis 21:50-56. 1977.

Rimler RB. Coagglutination test for identification of Pasteurella multocida associated with hemorrhagic septicemia. J Clin Microbiol 8:214218. 1978.

\section{TURKEY AIRSACCULITIS}

\section{Staff :}

KR Rhoades, DVM, PhD

JE Gallagher, BS

LL Ferguson, Technician

Research in this project is concerned primarily with turkey airsacculitis resulting from mycoplasmal infections. Emphasis is currently directed toward two objectives (1) improving methods for diagnosing infections with recognized pathogens; and (2) evaluating the importance of organisms, which are questionable so far as pathogenicity for turkeys is concerned.

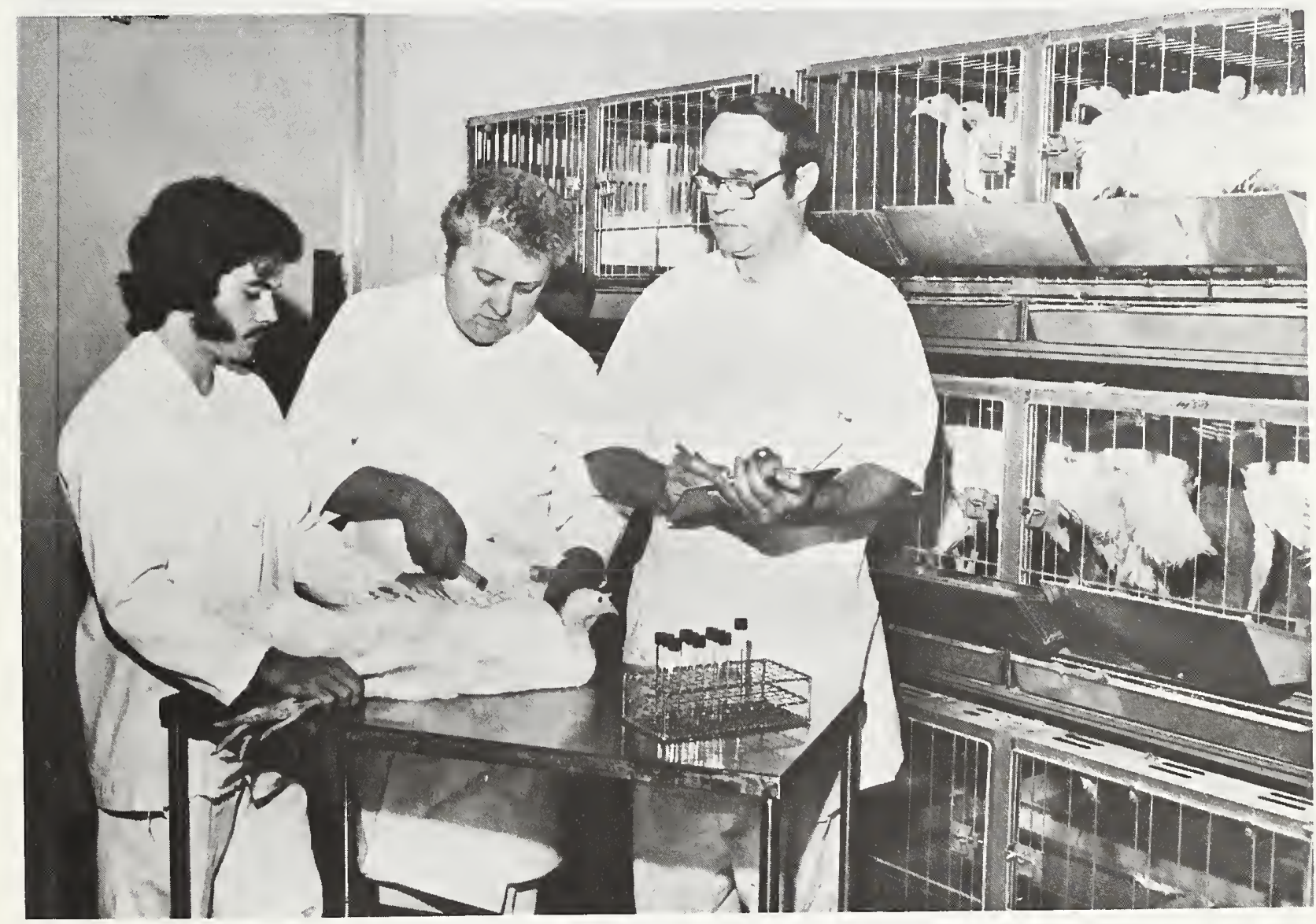

L. L. Ferguson, K. R. Rhoades, J. E. Gallagher (clockwise) 
Studies to improve diagnostic methods are concerned wtih serologic testing for specific antibody. The relationship between the results obtained with different types of tests and the predominating immunoglobulin class of which the specific antibody is composed are being studied, as is the particular type of antigen(s) that stimulate production of antibody detectable by the commonly used tests. A better understanding of these factors is expected to contribute toward explaining variations in test results; which often occur.

Studies to evaluate potential pathogenicity of mycoplasmas other than the currently recognized pathogens are being conducted with strains of the I-J-K-N-Q-R group. The ability of these organisms to produce airsacculitis, their transmissibility, their stimulation of antibody production, and their within-group antigenic, morphologic, and biochemic relationships are being studied.
Key Publications

Rhoades KR. Turkey sinusitis:

Synergism between Mycoplasma synoviae and Mycoplasma meleagridis. Avian Dis $21: 670-674.1977$.

\section{Current Publications}

Rhoades KR. Turkey sinusitis: Synergism between Mycoplasma synoviae and Mycoplasma meleagridis. Avian Dis 21:670-674. 1977 .

Rhoades KR. Inhibition of avian mycoplasmal hemagglutination by $\mathrm{IgM}$ type antibody. Poultry Sci 57:607610. 1978.

Rhoades KR. Comparison of Mycoplasma meleagridis antibodies demonstrated by tube agglutination and hemagglutination-inhibition tests. Avian Dis $22: 633-638$. 1978 .
BIOCHEMISTRY AND BIOPHYSICS

RESEARCH LABORATORY

AE Ritchie, MS--Acting Chief

MO Bornmueller--Secretary

This laboratory has a broad diversified program in close cooperation with scientists in the other laboratories of NADC. One function is to study the various aspects of the immune response of domestic animals toward bacterial, viral, and other immunogens and toxins. Concurrently, studies are directed toward isolating and characterizing various toxins, pathogens, and the associated immunogenic anti- gens by biochemical, biophysica1, and immunological methods. Other areas include clinical chemical research directed to detect and characterize changes in amiotic and allantoic fluid during episodes of disease terminating in abortion.

Some senior members hold staff appointments at Iowa State University, Department of Biochemistry and Biophysics, and Immunobiology. This permits them to offer special courses at the NADC and to act as advisors for graduate students pursuing Master of Science or Doctor of Philosophy degrees. 


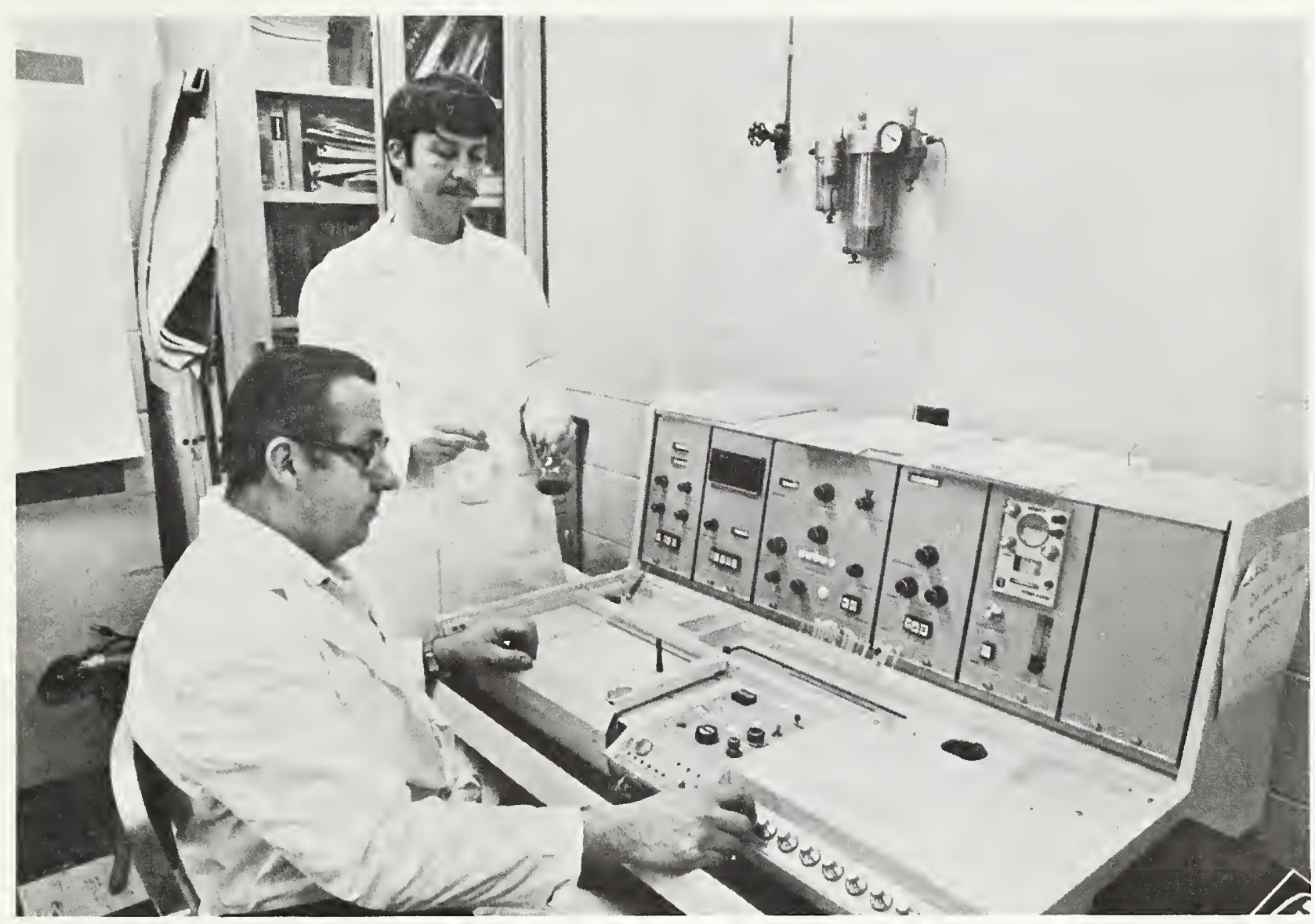

G. W. Engstrom, D. McDorman (clockwise)

MICROBIAL SECTION

\section{Staff:}

GW Engstrom, PhD

D McDorman, MS

JM Patterson, BS

AE Ritchie, MS

J Tinda11, BS

Research is directed toward isolating, purifying, and characterizing toxic and other bacterial and fungal metabolites and studying their effects on selected biochemical systems from animal tissue or microbial culture. A toxic cyclic peptide lactone, roseotoxin $B$, has been characterized using ion-exchange chromatography, mass spectroscopy, and proton and
Carbon-13 NMR spectroscopy. Other studies have involved high pressure liquid chromatography for anlyzing rubratoxin $B$ and other mycotoxins.

High resolution electron microscopy (Philips EM-200) is used to obtain morphological data on both bacteria and viruses. For bacteria, the main research objectives are to (1) characterize the microbial populations of various ecological niches; (2) establish taxonomica11y significant ultrastructural markers; (3) determine the occurrence of bacteriophages or their gene products in bacterial cultures and ascertain their effect on the physiological condition and pathogenicity of the host organism or 


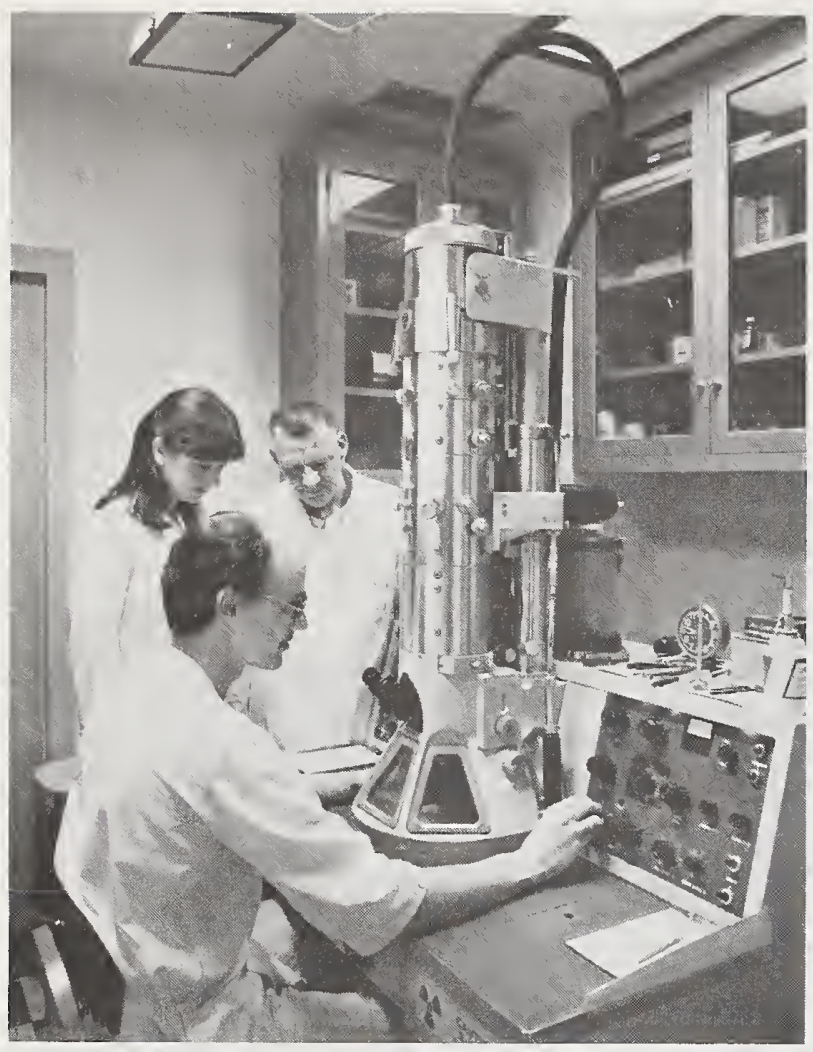

M. T. Jensen, J. Tindall, A. E. Ritchie (clockwise)

both; and (4) apply direct immunoelectron microscopy for differentiating closely related organisms and assessing the expression of capsular, endotoxic, or bacteriophage genes.

For viruses, the current emphasis is on determining the details of morphogenesis of those viruses that replicate by means of a "viroplasm," for example, adeno-, reo-, picodna- and picornaviruses. The objective is to obtain insight into the possibility of a common model of capsid assembly.

\section{Key Publications}

Engstrom GW, DeLance JV, Richard JL, Baetz AE. Purification and characterization of Roseotoxin B, a toxic cyclodepsipeptide from Trichothecium roseum. J Agric \& Food Chem 23:244253. 1975 .

McCullough WG, Merkal RS. Ironchelating compound from Mycobacterium avium. J Bact 138:15-20. 1976.

Ritchie AE. Morphology of leptospires. In: The Biology of Parasitic Spirochetes, edited by RC Johnson. Academic Press, NY, p 19-37. 1976.

\section{Current Publications}

Engstrom GW, Richard JL, Cysewski SJ. High pressure liquid chromatographic method for detection and resultion of rubratoxin, aflatoxin, and other mycotoxins. J Agric \& Food Chem $25: 833$. 1977 .

Ritchie AE. Direct immuno-electron microscopy: Some interpretive problems with routine viral diagnosis. Proc 20th Ann Mtg AAVLD. p 79-82. 1977.

Ritchie AE, Robinson IM, Joens LA, Kinyon JM. A bacteriophage for Treponema hyodysenteriae. Vet Rec 103: 33-34. 1978.

\section{ANALYTICAL SECTION}

\section{Staff:}

AL Baetz, PhD

MJF Schmerr, PhD

S Crande11, BS

KR Goodwin, Technician
Investigations in the analytical biochemistry laboratory are concerned with determining biochemical constituents in the body fluids and tissues of normal and diseased farm animals. Special emphasis are given to constituents found in bovine fetal fluids (allantoic, amniotic, plasma) 


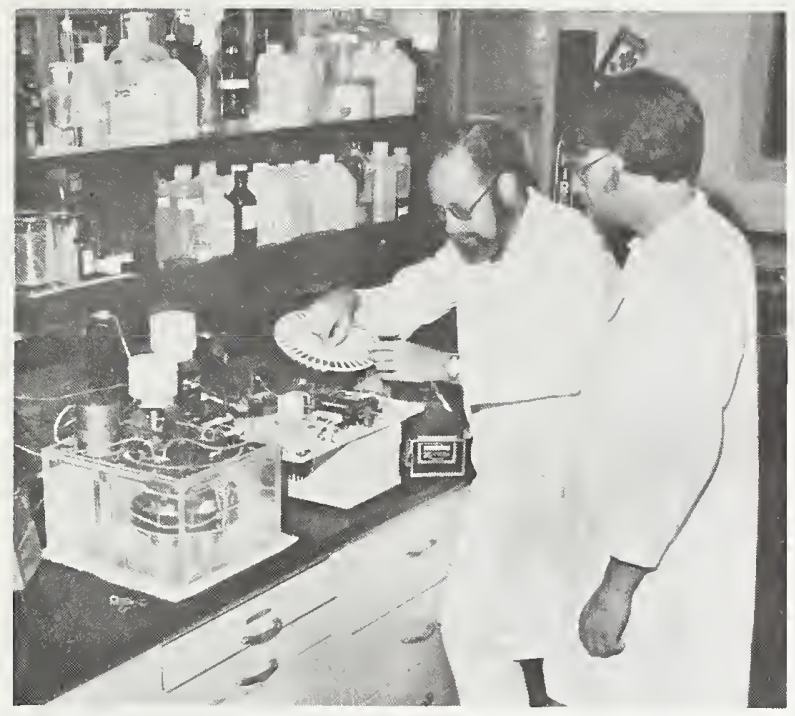

A. L. Baetz, T. Faidley (clockwise)

when the cow has been exposed to infectious agents that cause abortion.

\section{Key Publications}

Baetz AL, Hubbert WT, Graham CK. Developmental changes of free amino acids in bovine fetal fluids with gestational age and the interrelationships between the amino acid concentrations in the fluid compartments. J Reprod Fert 44:437-444. 1975.

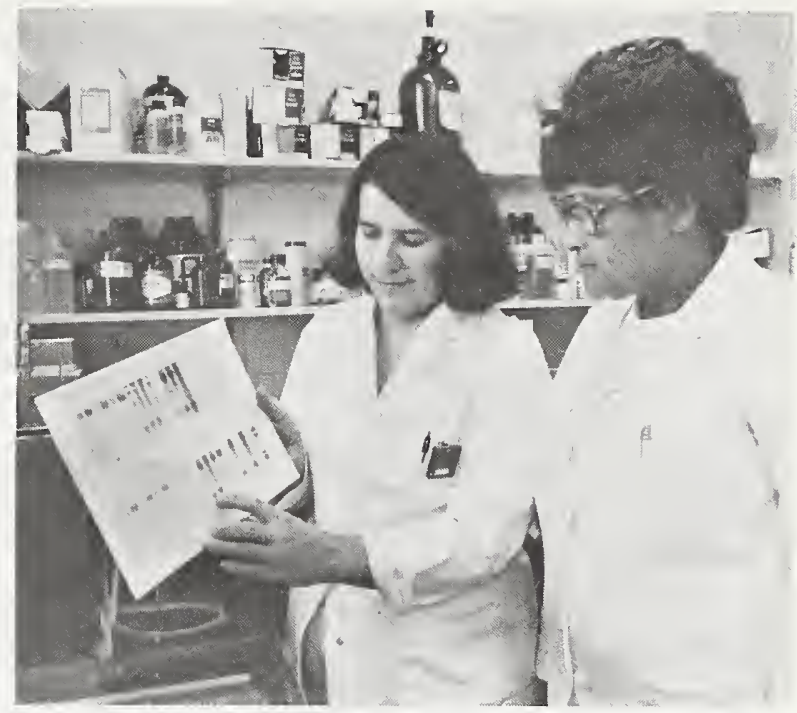

M.J.F. Schmerr, K. R. Goodwin (clockwise)

Baetz AL. The effect of fasting on blood constituents in domestic animals. Ann Rech Vet 7:105-108. 1976.

Baetz AL, Hubbert WT, Graham CK. Changes of biochemical constituents in bovine fetal fluids with gestational age. Am J Vet Res 37: 1047-1052. 1976.

\section{IMMUNOLOGICAL SECTION}

Staff:

PA Rebers, PhD

M Phillips, $\mathrm{PhD}$

S Stone, $\mathrm{PhD}$

MT Jensen, MS

D Ashby, BS

RE Patterson, Technician

The chemistry of vaccine components capable of inducing protection against fowl cholera and the nature of the protective factors induced in the host by these vaccines are under study.
The usual vaccines produced with artificial media are capable of inducing homologous protection, but live vaccines, or formalized infected tissue vaccine, are capable of inducing cross protection as well. Direct inoculation of some laboratory media with livers from turkeys that died of fowl cholera have also produced cross protective killed vaccines. The cross protection is due, at least in part, to humoral factors since the immunity can be passively transferred.

Methods were developed and are in use to characterize lipopolysaccharides 


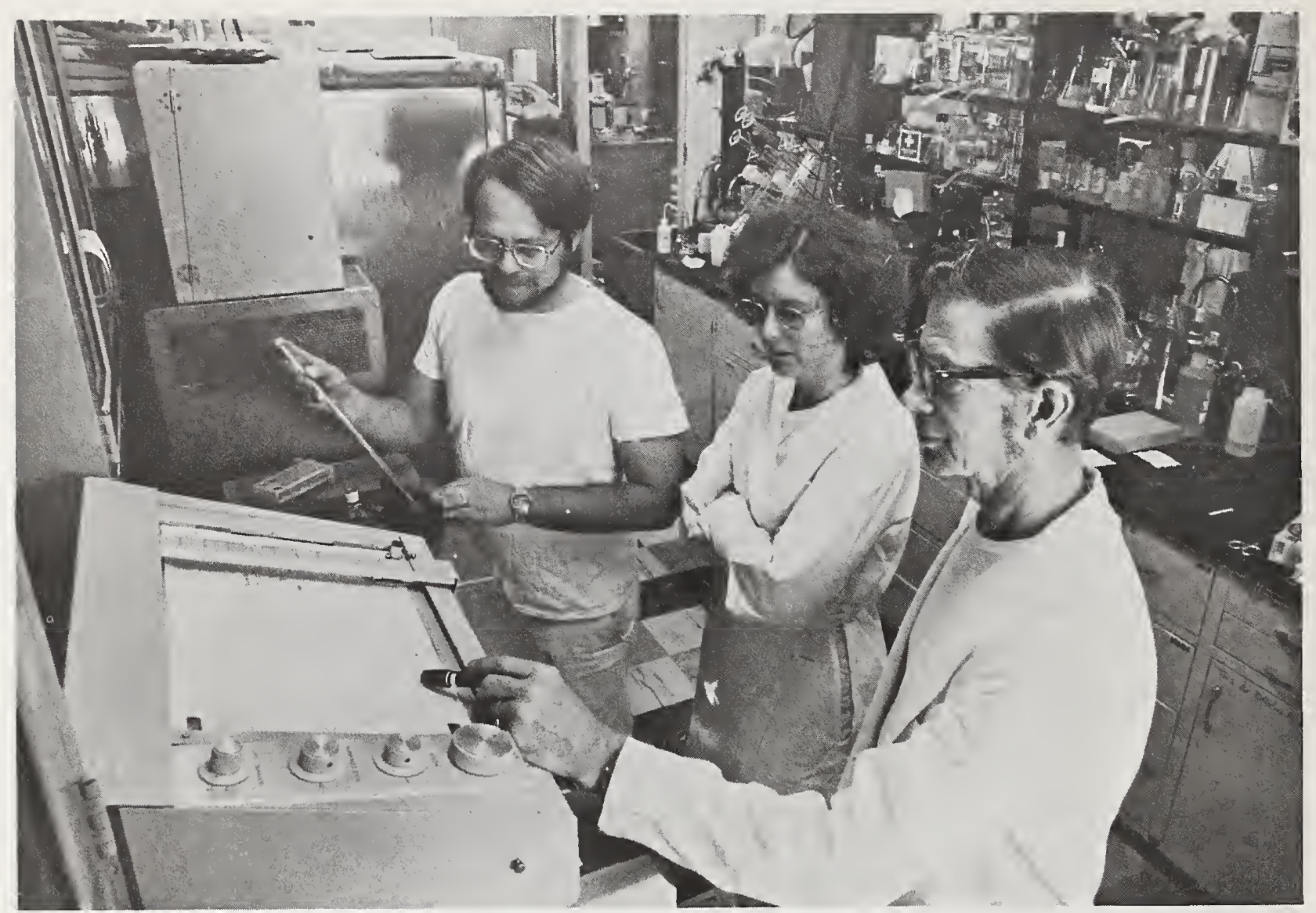

K. McKinney, D. Ashby, P. A. Rebers (clockwise)

from Pasteurella multocida by isopycnic methods in cesium chloride gradients. This procedure aids to identify the moiety from cell walls that may provide immunological specificity.

Studies are in progress to isolate, purify, and characterize toxins and toxic metabolites and specific antigens produced by Brucella organisms. These studies include determining the mechanism of toxin action at the cellular and molecular level in vitro and in vivo systems. A basic understanding of the pathogenicity and virulence of Brucella infection will contribute towards developing diagnostic and therapeutic techniques.
Methods are under study to isolate ribosomes from Brucella that may provide a degree of protection in cattle not attained with live vaccination as the immune response appears to be cell mediated with little or no indication of a humoral antibody.

Bovine leukemia research is directed toward characterizing viral and vira1related antigens. The major core protein ( $\mathrm{p} 24$ ) of the bovine leukemia virus has been purified and radiolabeled with $125 \mathrm{I}$ and has been used in a radioimmunoassay to monitor antibody levels in infected and vaccinated cattle and sheep. Another viral related antigen, a glycoprotein GP-58, has been isolated from the culture fluids of cells infected with bovine leukemia virus, and further character- 


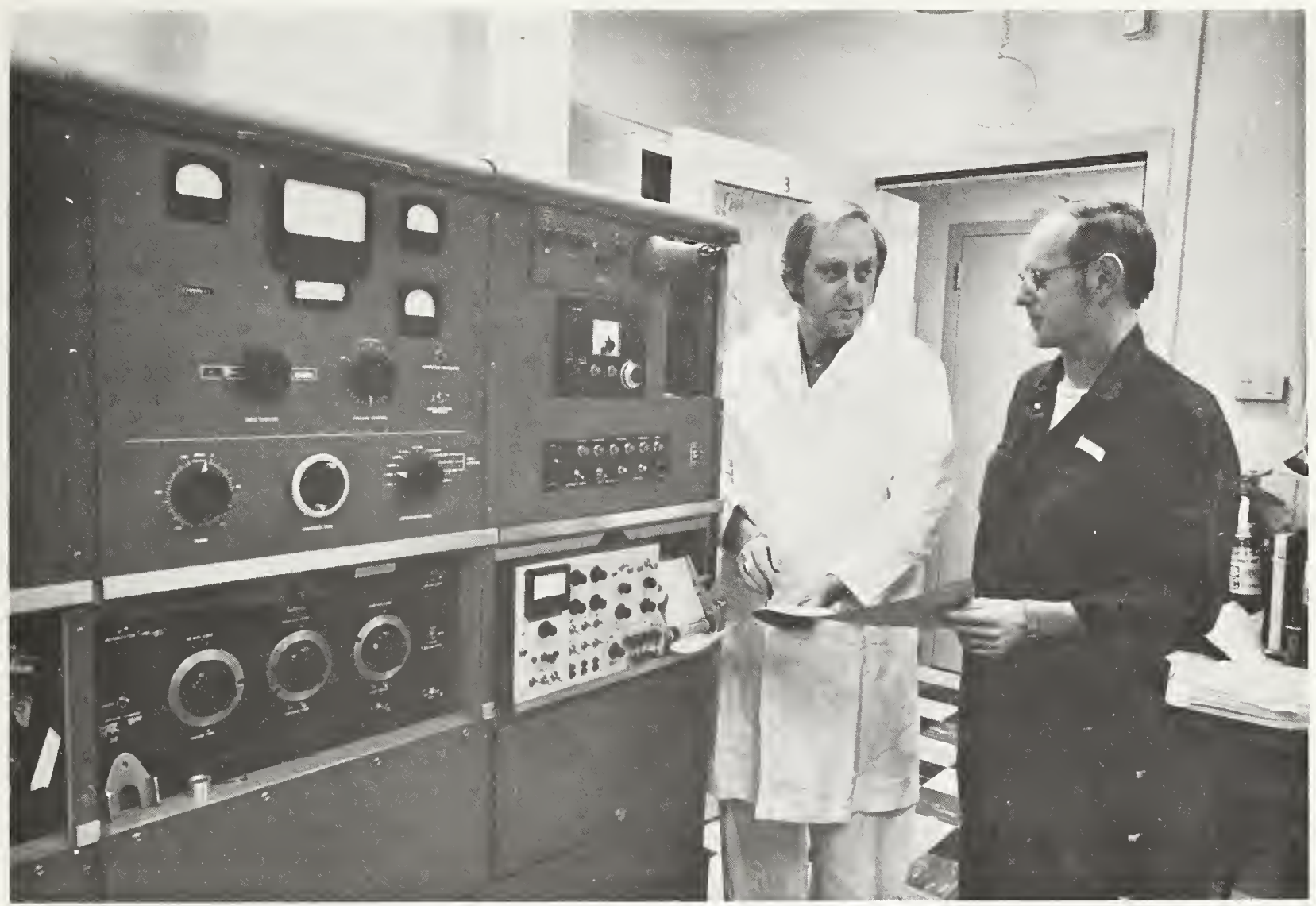

M. Phillips, R. E. Patterson (left to right)

ization of this glycoprotein is in progress. Studies are continuing with the virus and with other viruses; for example, transmissible gastroenteritis, to characterize subviral particles associated with these viruses for possible use as diagnostic aids and as immunogens to vaccines.

\section{Key Publications}

Patterson JM, Deyoe BL, Stone SS. Identification of immunoglobulins associated with complement fixation, agglutination, and low $\mathrm{pH}$ buffered antigen tests for Brucellosis. Am J Vet Res 37:319-324. 1976.

Rebers PA, Heddleston KL, Wright B, Gillette K. Fowl cholera: Crossprotective turkey antisera and IgG antibodies induced with Pasteurella multocida-infected tissue bacterins. Carbohydrate Res 40:99-110. 1975.

Stone SS, Kemeny LJ, Jensen MT. Partial characterization of the principal soluble antigens associated with the coronavirus of transmissible gastroenteritis by complement fixation and immunodiffusion. Infect Immun 13:521-526. 1976 .

\section{Current Publications}

Phillips M, Miller JM, Van Der Maaten MJ. Isolation of a precipitating glycoprotein antigen from cell cultures persistently infected with bovine leukemia virus. J Nat Cancer Inst 60:213-217. 1978.

Phillips M, Rebers PA. Isopycnic characterization of lipopolysac- 
charides from Pasteure11a multocida. Ana1 Biochem 85:265-270. 1978 .

Rebers PA, Heddleston PA. Fowl cholera: Induction of cross-protection in turkeys with bacterins prepared from host-passaged Pasteurella multocida. Avian Dis 21: 50-56. 1977.

Stone SS, Kemeny LJ, Woods RD, Jensen
MT. Efficacy of isolated colostral IgA, IgG, and $\operatorname{IgM}(\mathrm{A})$ to protect neonatal pigs against the coronavirus of transmissible gastroenteritis. J Am Vet Res 38: 1285-1288. 1977.

Tabatabai LB, Deyoe BL, Stone SS . Isolation and characterization of a toxic protein-rich fraction from Brucella abortus. Fed Proc 37:1826. 1978.

\section{PATHOLOGICAL RESEARCH LABORATORY}

NF Cheville, DVM, $\mathrm{PhD}, \mathrm{ACVP}--$ Chief DL Finch--Secretary

The Pathological Research Laboratory conducts research on infectious diseases of domestic animals with emphasis on pathogenesis. Major efforts are currently placed on enteric diseases of cattle, respiratory diseases of sheep, septicemic infections of birds, equine hematologic disorders, and bovine lymphosarcoma. Techniques for which expertise and equipment are available include gross tissue examination, histology, autoradiography, microcinematography, fluorescent microscopy, and transmission and scanning

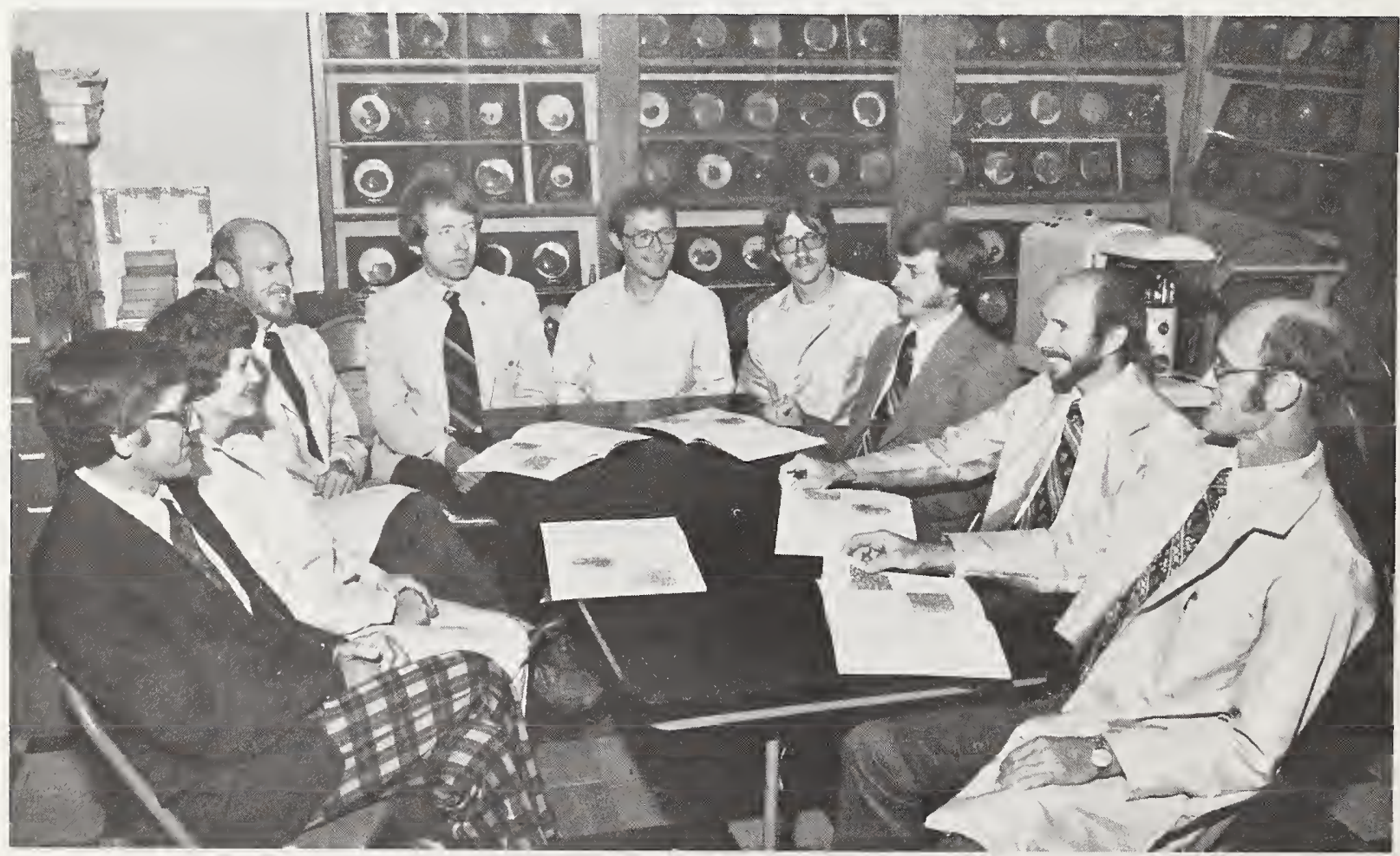

R. C. Cutlip, J. M. Millex, N. F. Cheville, T. A. Jackson, H. W. Moon, P. L. Runnells, H. D. Lehmkuhl, L. H. Arp, D. E. Barnett (clockwise) 
electron microscopy. Radiography, cell culture systems, biochemical techniques, and immunological methods are routinely used.

A weekly staff conference is conducted on histopathology in conjunction with the Armed Forces Institute of Pathology. Senior staff members may hold staff appointments in the College of Veterinary Medicine at Iowa State University and contribute to the teaching program of the graduate college. Courses in experimental pathology and enteric pathology are conducted by the pathology scientific staff and offered for credit at Iowa State University. Expertise for scientific collaboration is available from the staff at the University, its Veterinary Medical Research Institute, and the Veterinary Services Laboratory.

\section{CALF SCOURS}

\section{Staff:}

HW Moon, DVM, PhD, ACVP

$\mathrm{R}$ Isaacson, $\mathrm{PhD}$

PL Runnels, DVM

RA Schneider, BS

$\mathrm{K}$ Brown, MS

$P$ Sunday, BS

M Skartvedt, Technician

DJ Skortman, Technician

Two avenues and investigations are included in this project (1) mechanisms of intestinal colonization by enterotoxigenic Escherichia coli, and

(2) developing diagnostic methods. The first focuses on bacterial pili (such as K99, K88, and 987-P antigens) that facilitate adhesion of $\underline{E}$. coli to the microvilli of intestinal epithelial cells. In the electron micrograph at bottom, enteropathogenic E. coli are adherent to epithelial cell microvilli in the small intestine. The spike-like structures, which are the point of contact between bacterial and eukaryotic cells, are aggregated pili. Pilus morphology, chemistry, antigenicity, genetics, and eukaryotic host species specificity are under investigation. Antigenic characteristics are exploited in preparing experimental vaccines to protect against challenge with live, fully virulent bacteria and in de- veloping diagnostic reagents to identify enteropathogenic E. coli. Nonadhesive colonizing attributes of enteropathogenic E. coli, such as those that affect growth rate and survival in the intestine, are also of interest.

Diagnostic methods are currently based on investigating spontaneous cases of calf scours. The objectives are (1) to determine which of the numerous infectious agents currently known to have the ability to cause diarrheal disease in calves are present, and (2) to evaluate existing methods for detecting these agents. Many of the agents are marginal pathogens or opportunists and are widely spread in the population and carried by clinically normal animals. The greatest diagnostic challenge is to develop means to determine if the disease was caused by one or several of the agents in question. Specific agents of concerns are $\mathrm{E}$. coli, Salmonella, Cryptosporidia, Rotavirus, Coronavirus, bovine viral diarrhea virus, adenovirus, and chlamydia.

\section{Key Publications}

Isaacson RE. K99 surface antigen of Escherichia coli: Purification and partial characterization. Infect Immun 15:272-279. 1977. 
Isaacson RE, Morgan RL, Moon $\mathrm{HW}$, Brinton CC. Immunization against enterotoxigenic Escherichia coli infection by passive immunization with purified K99 pilus. Proc 13th Joint Conf on Cholera. 1977.

Isaacson RE, Nagy B, Moon HW. Colonization of porcine small intestine by Escherichia coli: Colonization and adhesions factors of pig enteropathogens which lack K88. J Infect Dis 135:531-539. 1977.

Moon HW. Mechanisms in the pathogenesis of diarrhea: A review. J Am Vet Med Assn 172:443-448. 1978.

Moon HW et al. Agedependent resistance to transmissible gastroenteritis of swine. Vet Path 12:434-445. 1975.

Moon $\mathrm{HW}$, McClurkin AW, Isaacson RE, Pohlenz J, Skartvedt SM, Gillette KG, Baetz AL. Pathogenic relationships or rotavirus, Escherichia coli, and other mixed infections in calves. J Am Vet Med Assn 173:557-583. 1978.

Moon HW, Nagy B, Isaacson RE, Ørskov I. The occurrence of $\mathrm{K} 99$ antigen on Escherichia coli isolated from pigs and colonization of pig ileum by K99+ enterotoxigenic $\underline{E}$. coli from calves and pigs. Infect Immun 15:614-620. 1977.

Moon HW, Whipp SC, Baetz AL. Comparative effects of enterotoxins from Escherichia coli and Vibrio cholerae on rabbit and swine small intestine. Lab Invest 25:133-140. 1971.

Nagy B, Moon HW, Isaacson RE. Colonization of porcine intestine by entero- toxigenic Escherichia coli. Selection of piliated forms in vitro adhesion of piliated forms to epithelial cells in vitro and incidence of a pilus antigen among porcine enteropathogenic $E$. coli. Infect Immun 16:344-352. 1977.

Nagy $B$, Moon HW, Isaacson RE, To CC, Brinton CC. Immunization of suckling pigs against enteric enterotoxigenic Escherichia coli infection by vaccinating dams with purified pili. Infect Immun 21:269-274. 1978.

Pohlenz J, Bemrick WJ, Moon HW, Cheville NF. Bovine cryptosporidiosis: A transmission and scanning electron microscopic study of some stages in the life cycle and of the hostparasite relationship. Vet Path $15: 417-427.1978$.

\section{Current Publications}

Moon HW, Nagy B, Isaacson RE. Intestinal colonization and adhesion by enterotoxigenic E. coli. J Infect Dis 136:S124-S129. 1977 .

Moon HW, Fung PY, Whipp SC, Isaacson RE. Effects of age and ambient temperature on the response of infant mice to heat-stable enterotoxin of Escherichia coli. Infect Immun 20:36-39. 1978 .

Moon HW, Nagy B, Isaacson RE. Intestinal colonization and adhesion by enterotoxigenic E. coli. J Infect Dis $136:$ S124-S129. 1977.

Pohlenz J, Moon HW, Cheville NF, Bemrick WJ. Cryptosporidiosis as a probable factor in neonatal diarrhea of calves. JAVMA 172:452-457. 1978.

RESPIRATORY DISEASES OF SHEEP

Staff:

RC Cutlip, DVM, PhD, ACVP

TA Jackson, DVM, PhD, ACVP

HD Lehmkuh1, PhD

GA Laird, Technician

JE Lenius, Technician

MS Brown, Technician 
Research is devoted to identifying and characterizing individual disease entities, determining their prevalence and etiology, and evaluating the pathogenetic mechanisms of disease. Current studies are concerned with establishing progressive pneumonia in experimental animals and with the factors that enhance or impede susceptibility and control of spontaneous disease. Progressive pneumonia of sheep (PPS) is a slow viral disease endemic in the Rocky Mountain region and is similar to maedi in Iceland, zwoegersiekte in Holland, and so forth. It is traditionally confused with pulmonary adenomatosis, a disease whose insidious onset and slow progression closely simulate those of PPS. PPS is a chronic ailment with insidious onset and slow relentless progression to death. Sheep are 2 years or older before signs of disease are seen, and fatalities result from 6 months to 1 year later. The cardinal feature is impairment of pulmonary function by massive numbers of $1 \mathrm{ym}-$ phoid cells in the lungs.

The causal virus has been isolated in cell culture and an agar gel immunodiffusion test developed to detect precipitating antibody to the virus. Using this test, the incidence of ovine progressive pneumonia was from less than 1 percent to more than 60 percent of old sheep at slaughter in different states in the United States.
Virus isolation and pathologic changes corroborated the findings.

In studies of lymphocyte kinetics in sheep, cannulation techniques have been developed for the efferent lymph vessels of the prescapular and popliteal lymph nodes, as well as the thoracic duct. Lymphocytes collected by these techniques are examined for general properties.

Key Publications

Cutlip RC, Laird GA. Isolation and characterization of a virus associated with progressive pneumonia (maedi) of sheep. Am J Vet Res 37:1377-1382. 1976.

\section{Current Publications}

Cutlip RC, Jackson TA, Laird GA. Immunodiffusion test for ovine progressive pneumonia. Am J Vet Res 38:1081-1084. 1977.

Cutlip RC, Jackson TA, Laird GA. Prevalence of ovine progressive pneumonia in a sampling of cull sheep from Western and Midwestern United States. Am J Vet Res 38:2091-2093. 1977.

Cutlip RC, Jackson TA, Lehmkuh1 HD. Diagnostic features of ovine progressive pneumonia. JAVMA 173: 1578-1579. 1978 .
RESPIRATORY AND SEPTICEMIC DISEASES OF POULTRY

\section{Staff:}

$\overline{\mathrm{NF}}$ Cheville, DVM, PhD, ACVP

LH Arp, DVM

DI Buck, Technician

LR E1liott, Technician

A Jensen, Technician

T Bertram, Technician
Research centers on colisepticemia in turkeys. One of the major problems in the turkey industry, this disease is characterized by both respiratory and enteric infection. Bacteria are recovered from the tissues of dying birds and are responsible not only for death but for failure to thrive after recovery. Isolates of Escherichia coli are being serotyped and examined 
for pathogenicity in view of vaccine production. Pathogenesis studies are designed to elucidate the ways in which bacteria pass the intestinal barrier and how they are cleared from the cloacal bursa. The role of the phagocytic bursal pad is being analyzed in the persistence of pathogenic E. coli in the bursa.

An adenovirus associated with severe outbreaks of disease has been isolated. Research on the pathogenesis of this disease and its associated bacterial superinfection entail its experimental reproduction and sequential examination of infected tissues. It has been found that immunosuppression is required to uniformly induce disease with this virus and that the respiratory system is susceptible to infection. The virus is being grown in vitro, and the usefulness of the culture for vaccine production will be studied.

\section{Current Publications}

Cheville NF, Arp LH. Comparative pathologic findings of Escherichia coli infection in birds. JAVMA

173:584-587. 1978 .

Cheville NF, Beard CW. Cytopathology of Newcastle disease. The influence of bursal and thymic lymphoid systems in the chicken. Lab Invest 27:129143. 1972.

Cheville NF, Okazaki W, Lukert PD, Purchase HG. Prevention of oncornavirus-induced lymphoid leukosis in chickens with infectious bursal virus. Vet Path 15:376-382. 1978.

Cheville NF, Sato S. The pathology of adenoviral infection in turkeys

(Meleagris gallopavo) associated with respiratory disease and colisepticemia. Vet Path 14:567-581. 1977.
HEMATOLOGIC DISEASES OF HORSES AND CATTLE

\section{Staff:}

D Barnett DVM, ACVP

DI Buck, Technician

JK Carter, BS

JD Dunshee, Technician

Major emphasis has been on the pathogenesis of bovine sarcosporidiosis and the mechanisms of acute muscle injury and abortion. Merogenous phases of Sarcocystis cruzi were demonstrated by light, immunofluorescent, and electron microscopy in the viscera and placenta of experimentally infected cows. Fluorescent antibody staining of sections of placental caruncles was developed as a practical diagnostic test for sarcocystis-induced abortion. The pathogenesis of equine viral arteritis is being studied with emphasis on platelet kinetics, coagulation factors, and the fibrinolytic system. Current research involves viral isolation from and fluorescent antibody staining of fetal tissues to elucidate the role of equine viral arteritis in abortion.

\section{Current Publications}

Barnett D, Carter JK, Hughes DE, Baetz AL, Fayer R. Practicable diagnosis of acute bovine sarcocystosis causally related to bovine abortion. Am Assn Vet Lab Diag 20:131-138. 1977. 
Staff:

MJ VanDerMaaten, DVM, PhD

RM Vegors, Technician

SL Hay, BS

JM Miller, DVM, PhD, ACVP

MJ Schmerr, PhD

KR Goodwin, Technician

M Phillips, PhD

The bovine lymphosarcoma research project is a multidisciplinary effort including staff members from the Virological, Pathology, and Biochemistry-Biophysics Research Laboratories. Research investigations are broad in scope but oriented toward solving practical problems encountered by livestock producers rather than investigating the basic biology of malignant neoplasms. Studies to date have contributed significantly to the etiologic significance of bovine leukemia virus and have resulted in the development of practical diagnostic tests to identify infected animals. Current research efforts include (1) studying potential avenues that transmit bovine leukemia virus and evaluating various husbandry methods, which may be used to prevent such transmissions; (2) developing and testing inactivated bovine leukemia virus vaccine preparations for use in controlling the spread of infection within cattle herds; and (3) separating and purifying bovine leukemia virus components for use in radioimmunoassay procedures and applying such assays in research studies.

\section{Current Publications}

Miller JM, VanDerMaaten MJ. Use of glycoprotein antigen in the immunodiffusion test for bovine leukemia virus antibodies. Europ J Cancer 13:1369-1375. 1977.

Miller JM, VanDerMaaten MJ. Attempts to control spread of bovine leukemia virus infection in cattle by serologic

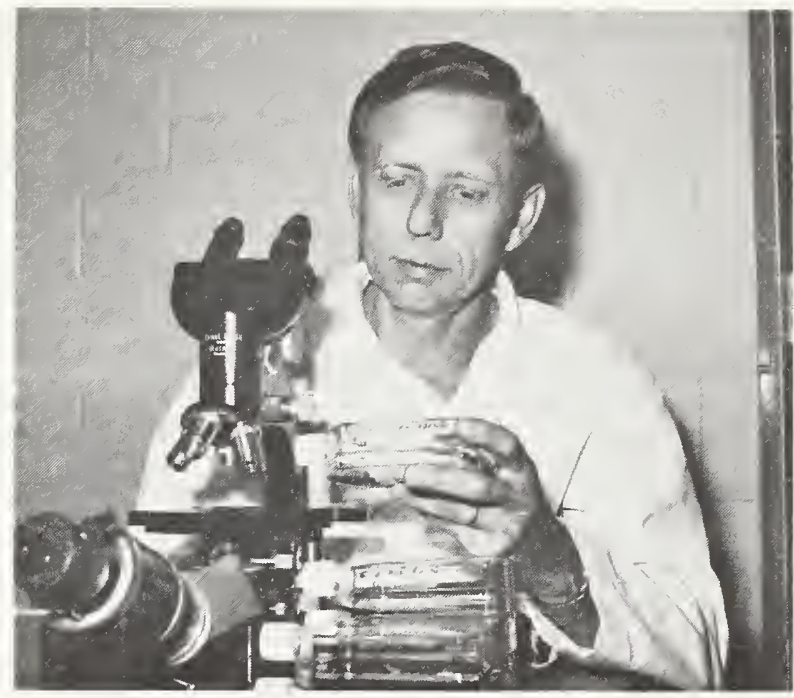

M. J. Van Der Maten, Jr.

surveillance with the glycoprotein agar gel immunodiffusion test. The Serological Diagnosis of Enzootic Bovine Leukosis, AA Ressang, ed. Commission of the European Communities, pp 127-133. 1978.

Miller JM, VanDerMaaten MJ. Infectivity test of secretions and excretions from cattle infected with bovine leukemia virus. J Natl Cancer Inst $62: 425-428.1978$.

Phillips M, Miller JM, VanDerMaaten MJ. Isolation of a precipitating glycoprotein antigen from cell cultures persistently infected with bovine leukemia virus. J Natl Cancer Inst $60: 213-217.1978$.

VanDerMaaten MJ, Miller JM. A comparison of the virus neutralization and glycoprotein agar-gel immunodiffusion tests for the detection of early serologic responses to bovine leukemia virus infection. The Serological Diagnosis of Enzootic Bovine Leukosis, AA Resssang, ed. Commission of the European Communities, pp 92-97. 1978.

VanDerMaaten MJ, Miller JM. Sus- 
Comparative Leukemia Research 1977, B Hilgers and Yohn, eds. pp 29-32. 1978. ceptibility of cattle to bovine leukemia virus infection by various routes of exposure. Advances in

\section{VIROLOGICAL RESEARCH LABORATORY}

ML Mengeling, DVM, FhD, ACVM--Chief DC Wilken--Secretary

Research is conducted on economically significant diseases of livestock and poultry caused by viral or chlamydial agents. Studies involve various immunological, biochemical, and biophysical techniques; cell culture systems; and animal inoculations. Defined populations of experimental animals and excellent isolation facilities are available. Basic studies are conducted on virus-cell interactions and host responses using ultracentrifugation; ultrafiltration; fluorescent and electron microscopy; and radiochemical techniques.

Members of the Virological Research Laboratory staff may hold appointments in the Graduate College and College of Veterinary Medicine at Iowa State University. In this capacity, they advise graduate students and occasionally lecture to graduate and undergraduate classes. Visiting scientists from other laboratories in this country and abroad may, by special arrangement, join the Laboratory staff to conduct specific investigations and experiments of mutual interest and the contribution to the research goals of the National Animal Disease Center.
ENTERIC DISEASES OF CATTLE

Staff:

$\overline{\mathrm{AW}} \mathrm{McCl}$ urkin, DVM, $\mathrm{PhD}$

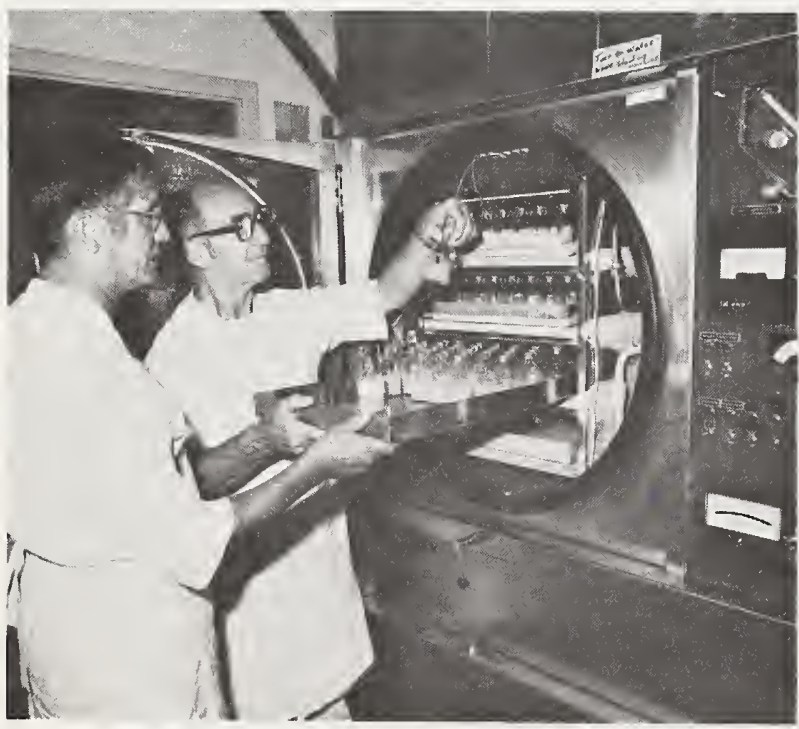

M. F. Coria, A. W. McClurkin (left to right)
MF Coria, PhD

RG Marsha11, BS

RL Smith, Technician

SL Stark, Technician

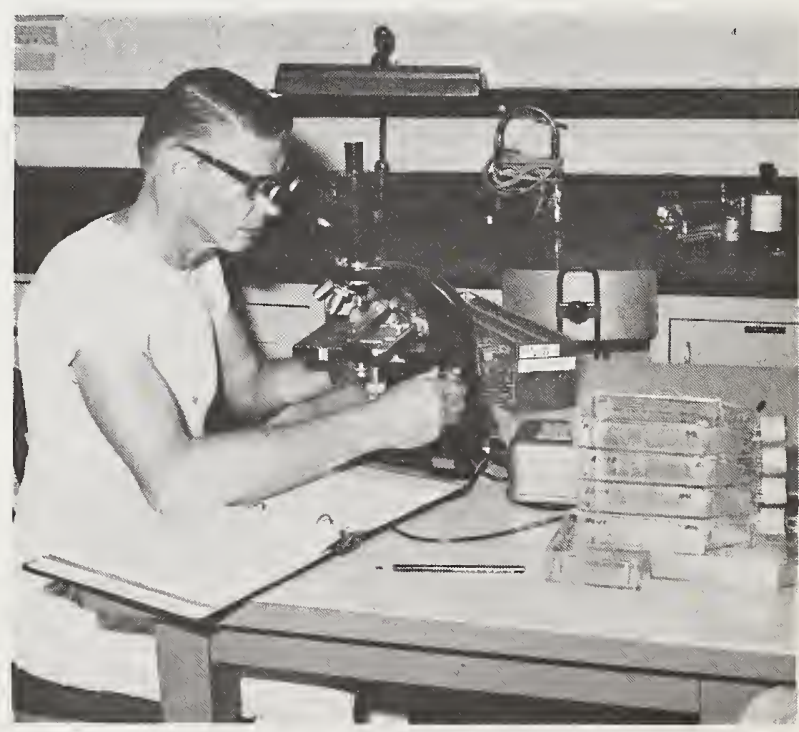

R. G. Marsha11 
This project studies viruses associated with intestinal diseases of cattle and calves, viruses associated with neonatal diseases of calves including "weak-calf syndrome," and viruses that may cause intrauterine infections of the fetus resulting in fetal death and abortion or abnormalities in the newborn calf.

Bovine viral diarrhea virus (BVD), isolated aborted fetuses, neonatal calf diseases, and an acute disease of cattle manifested by elevated temperature; diarrhea; nasal discharges; and erosion of the rumen lining, abomasum, and intestine are studied to improve diagnostic procedures needed to isolate the virus and define the diseases that are associated with the virus. A killed virus BVD vaccine was developed and used in both experimental cattle and field cattle to study the influence of the killed vaccine on preventing diseases of the cattle population associated with BVD.

Research on bovine adenoviruses, isolated from "weak-calf syndrome" and other disease conditions of cattle, is studied to improve diagnostic methods and to determine the incidence of these viruses in the cattle population. Defining the nature of the experimental disease caused by the viruses is undertaken to assist veterinarians in recognizing diseases associated with bovine adenoviruses.

Research on bovine parvoviruses is carried out to develop diagnostic methods that will enable diagnosticians to determine the incidence of the virus in different disease conditions. The experimental disease is also studied both in pregnant cattle and calves to determine the nature of the disease conditions caused by bovine parvovirus and to help define disease conditions that could be recognized under field conditions as possibly caused by the virus.

\section{Current Publications}

Coria MF, Lehmkuh1 HD. Isolation and identification of a bovine adenovirus type-3 with an adenovirus-associated virus. Am J Vet Res 39:1904-1906. 1978.

Coria MF, McClurkin AW. Duration of active and colostrum-derived passive antibodies to bovine viral diarrhea virus in calves. Can J Comp Med 42: 239-243. 1978.

Coria MF, McClurkin AW. Isolation of bovine adenovirus type-1 without an adenovirus-associated virus. Am J Vet Res 39:1975-1976. 1978.

Coria MF, McClurkin AW. Specific immune tolerance in an apparently healthy bull persistently infected with bovine viral diarrhea virus. J Am Vet Med Assoc 172:449-451. 1978.

McClurkin AW. Probable role of viruses in calfhood diseases. J Dairy Sci 60:278-282. 1977.

McClurkin AW, Coria MF. Selected isolates of bovine viral diarrhea (BVD) virus propagated on bovine turbinate cells: Virus titer and soluble antigen production as factors in immunogenicity of killed BVD virus. Archives of Virology 58:119--125. 1978. 
RESPIRATORY AND REPRODUCTIVE DISEASES OF SWINE

\section{Staff:}

TT Brown Jr, DVM, PhD, ACVP

WL Mengeling, DVM, PhD, ACVM

PS Paul, DVM, PhD, ACVM

PP Williams, PhD

KS Halloum, Technician

A Morgan, BS

G Wessman, Technician

DB Ducor, Technician

Currently, reproductive disorders caused by porcine parvovirus and swine influenza virus are under investigation. Individual experiments are designed to evaluate the effect of selected viruses on the developing fetus, the stages of gestation when the embryo or fetus is most vulnerable to infection and injury, the pathogenesis of infection in the fetus, the response of the fetus to the infectious agent, the economic importance of the reproductive problems caused by the viruses, and the ways to prevent such reproductive failure.

Mycoplasmal pneumonia is a chronic disease having a significant healtheconomic impact to the swine industry. In field outbreaks, the disease, initiated by the etiological agent Mycoplasma hyopneumoniae, is complicated by secondary microbiallungworm-environmental factors. Attempts to prevent the disease have been based on eliminating $\underline{M}$. hyopneumoniae from swine herds. Recent$1 y$, interest was expressed in the immunoprophylaxis of this disease. The reason for this, primarily, was the knowledge that a stable immunity occurs in swine after experimental infection. Currently, basic and applied research are concerned with reducing $\underline{M}$. hyopneumoniae infections in swine. Specific experiments include (1) infecting gnotobiotic and naturally farrowed pigs with $\underline{M}$. hyopneumoniae and collecting respira-

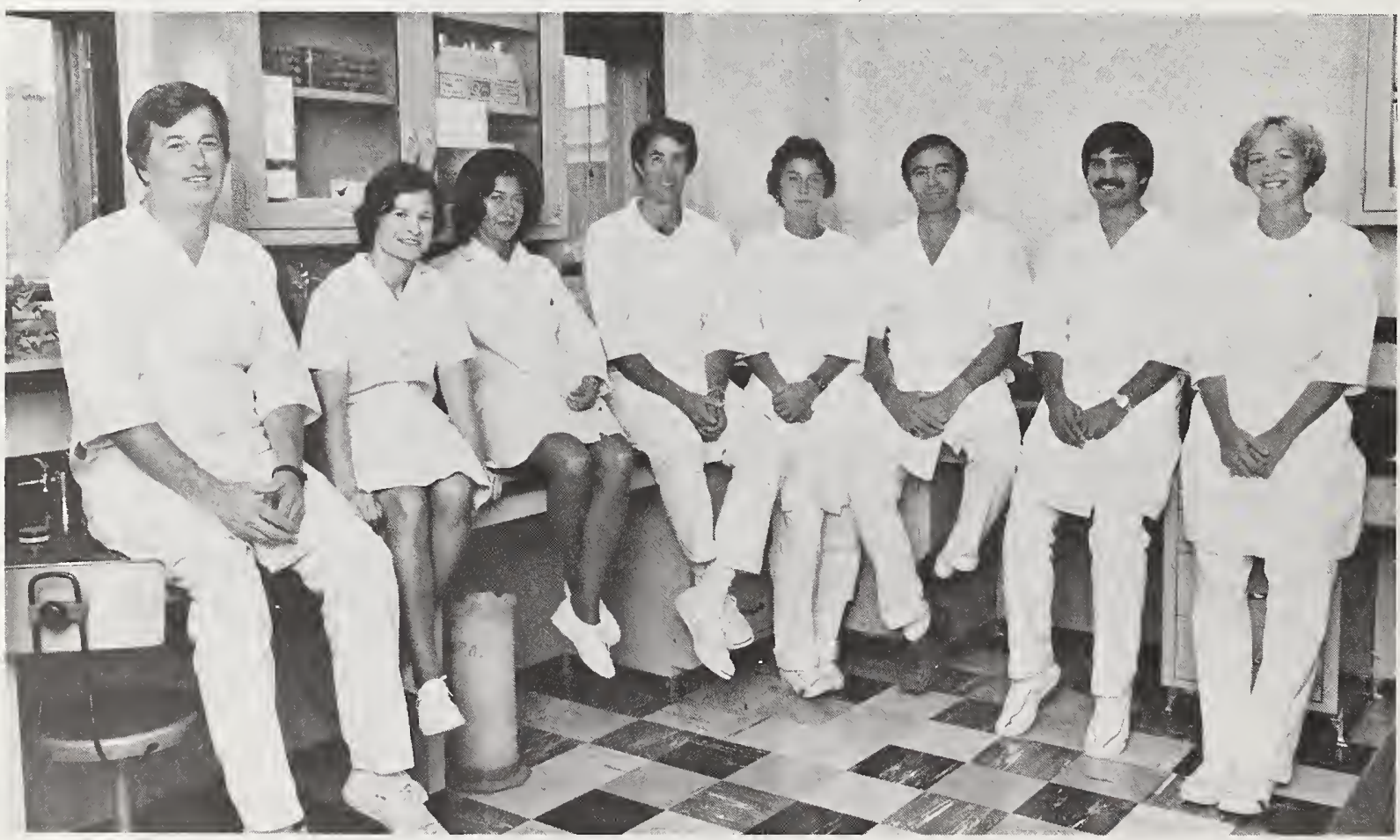

P. P. Williams, K. S. Halloum, G. Wessman, T. T. Brown, Jr., A. Vorwald, W. L. Mengeling, P. S. Paul, A. Morgan (clockwise) 
tory lavage for detecting the organism by cultivation procedures, and (2)

elucidating the immune response of the pig to this organism and determining a means of stimulating this response without infecting the animal, for example, by vaccination.

\section{Current Publications}

Mengeling WL. Diagnosing porcine parvovirus-induced reproductive failure. 20th Proc Am Assoc Vet Lab Diag, pp 237-244. 1977.

Mengeling WL. Elimination of porcine parvovirus from infected cell cultures by inclusion of homologous antiserum in the nutrient medium. Am J Vet Res $39: 323-324$. 1978 .

Mengeling WL. Porcine parvovirusinduced reproductive failure, encephalitis-vomiting and wasting disease syndrome, and SMEDI. Short chapters in Current Veterinary
Therapy in Food Animal Practice, edited by JL Howard. WB Saunders Co, Philadelphia, PA. 1978.

Mengeling WL. Prevalence of porcine parvovirus-induced reproductive

failure: An abattoir study. J Am Vet Med As soc 172:1291-1294.

Mengeling WL, Cutlip RC, Barnett D. Porcine parvovirus: Pathogenesis, prevalence, and prophylaxis. Proc 5th Internatl Pig Vet Congr, Zabreg, Yugoslavia. 1978.

Pirtle EC. Evaluation of $\mathrm{A} / \mathrm{New}$ Jersey/76 influenza whole-virus vaccine in hysterectomy-derived pigs. J Infect Dis 136 (Supp1):S702S705, Dec 1977.

Williams PP. Collection and cultivation of and phagocytosis by pulmonary macrophages obtained from hysterectomyderived pigs. Am J Vet Res 39:485-489. 1978.
VIRAL ENTERIC DISEASES OF SWINE

\section{Staff:}

LJ Kemeny, DVM

RD Woods, PhD

VL Wiltsey, Technician

LC Escher, Technician

Basic and applied research are conducted on methods to prevent and control swine enteric viral diseases. Research concerns the identification and the physiocochemical characteristics of the etiological agents and their antigens. The cellular and humoral immune responses in swine exposed to these viruses are investigated to define their role in preventing a reinfection or facilitating recovery from an infection. Developing an in vivo or in vitro diagnostic test to detect carrier swine and identifying the conditions that result in the shedding of infectious virus

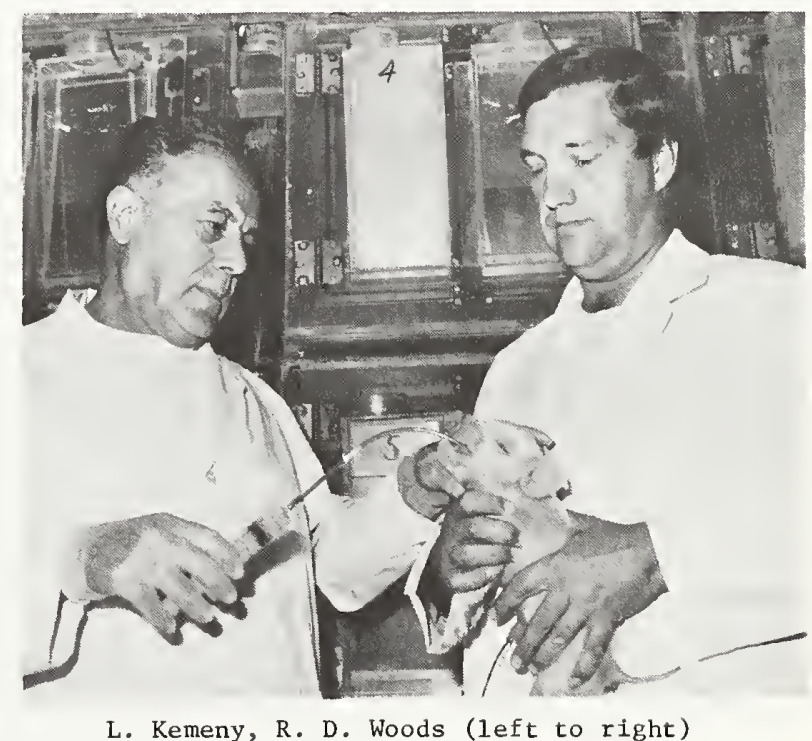


from these carrier swine is of major importance. The final goal of the research is to control the disease by eradicating or selecting an attenuated virus strain that could be used to vaccinate pregnant sows and gilts so they would provide the immunity for their suckling pigs against a virulent virus challenge.

\section{Current Publications}

Kemeny LJ. Isolation of transmissible gastroenteritis virus from pharyngeal swabs obtained from sows at slaughter. Am J Vet Res 37:703-705. 1978.

Kemeny LJ, Woods RD. Quantitative transmissible gastroenteritis virus shedding patterns in lactating sows. Am J Vet Res 28(3):307-310. 1977.
Mocsari E, Stone SS. Colostral IgA, IgG, and IgM-IgA fractions as fluorescent antibody for the detection of the coronavirus of transmissible gastroenteritis. Am J Vet Res 39: 1442-1446. 1978.

Woods RD. Characterization of transmissible gastroenteritis virus in establishment of persistent infection in swine lymphoid cells. J Supramolecular Structure 7:246. 1978.

Woods $\mathrm{RD}$. Leukocyte migrationinhibition procedure for transmissible gastroenteritis viral antigens. Am J Vet Res 38(8):1267-1269. 1977.

Woods RD. Small plaque variant transmissible gastroenteritis virus. J Am Vet Med Assoc (Part 2):643-647. 1978.

\section{ORNITHOSIS IN POULTRY}

Staff:

LA Page, PhD

WA Boney, Jr, DVM, MS

J Tessler, MS

JA Wells, Technician

MD McFarland, Technician

VP Meador, Technician

Ornithosis (avian chlamydiosis) is an infectious, debilitating, sometimes fatal disease of birds caused by the bacterium Chlamydia psittaci. Chlamydiae are widely distributed among wild and domestic animals, especially birds, and cause pneumonic, septicemic, enteric, arthritic, and reproductive diseases of birds and mammals, including man.

Virulent chlamydial strains of undetermined origin cause spordic, localized outbreaks in domestic turkeys. Economic losses result from bird mortality, weight losses, reproductive failure among breeders, expense of antibiotic treatment, and condemnations of birds at processing plants. Furthermore, epidemics of pneumonic chlamydiosis (psittacosis) among processing plant employees occur wherever infected birds were sent for processing.

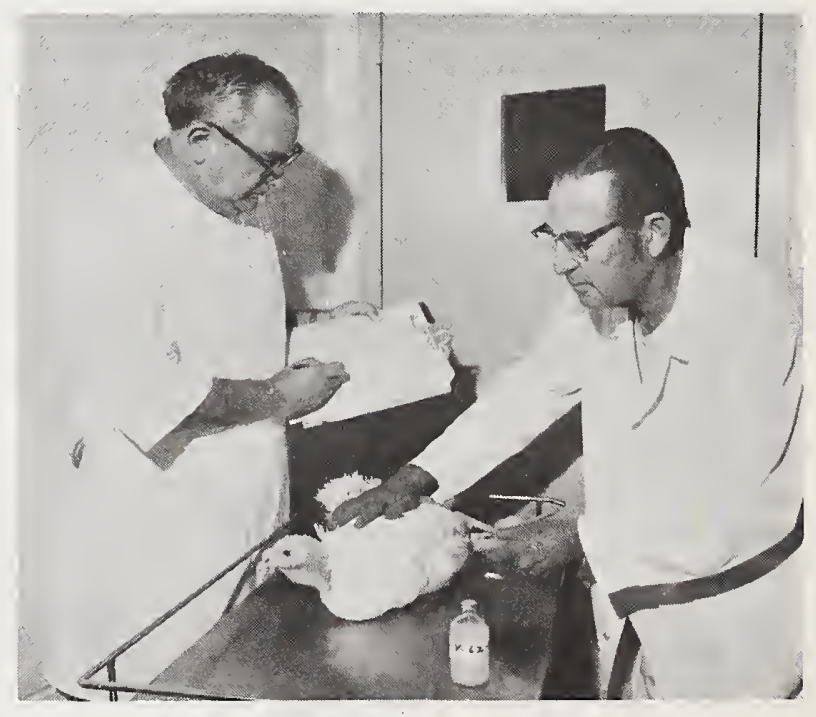

J. Tessler, W. A. Boney, Jr. (left to right) 
Research approaches used at NADC to improve methods for control of ornithosis are to (1) develop effective vaccines to protect birds raised in high risk areas and identify mechanisms of immunity; (2) improve diagnostic procedures by developing rapid serologic and immunofluorescent tests for the disease; (3) update regimens for antibiotic therapy of the disease to prevent development of latent infections and antibiotic resistance; and (4) identify ornithosis-carrying species among wildlife and determine mechanisms of transmission.

\section{Current Publications}

Grimes JE and Page LA. Comparison of direct and modified direct complement fixation and agar gel precipitin methods in detecting chlamydial antibody in wild birds. Avian Dis $22: 422-430$. 1978 .

Page LA. The Chlamydiae. Chapter in Handbook of Microbiology, Vo1. 1,
Organismic Microbiology, 2nd Ed., eds. AI Laskin and HA Lechevalier. CRC Press, Cleveland, OH, pp 397-404. 1977.

Page LA. The Chlamydiae. Chapter in Handbook Series in Nutrition and Food, ed. M. Rechcig1, Jr, CRC Press, pp 3136. 1977.

Page LA. Stimulation of cell-mediated immunity to chlamydial bacterin. inoculation of chlamydial bacterin. Am $\mathrm{J}$ Vet Res 39:373-480. 1978.

Page LA and Lattimer GL. Detection of complement fixing antibodies to Legionnaire's disease bacterium and chlamydia in human and animal sera. Current Microbiol 1 (No. 6):331334. 1978.

Tessler $\mathrm{J}$ and Page LA. Optimal macroculture method for studying mitogenic stimulation of turkey lymphocytes. Can J Comp Med $42: 249-252$. 1978 .
PSEUDORABIES

Staff:

DE Gutekunst, DVM, MS

EC Pirtle, PhD

HR Hill, Technician

SK Puderbaugh, Technician

Areas of research on pseudorabies virus (PRV) infections of swine involve (1) developing and evaluating diagnostic tests, (2) investigating the role of cellular and humoral immunity in the prevention of and recovery from PRV infection, (3) developing an effective inactivated vaccine to prevent clinical disease, (4) studying the ontogeny of immunoglobulins in infected swine, and (5) determining the factor involved with latency of the virus in infected swine.
Current Publications

Gutekunst DE. Detection of pseudorabies viral antibody by the microimmunodiffusion test. JAVMA 172: 1072. 1978.

Gutekunst DE. Immune responses in swine given 1ipid-conjugated pseudorabies (Aujeszky's disease) viral antigens. Proc 5 th Int1 Pig Vet Soc, Zagreb, Yugoslavia, KB.58. 1978.

Gutekunst DE. Immune responses in swine given 1ipid-conjugated pseudorabies viral antigens. Am J Vet Res 39:1435-1437. 1978.

Gutekunst DE and Pirtle EC. Microimmunodiffusion test for assaying 


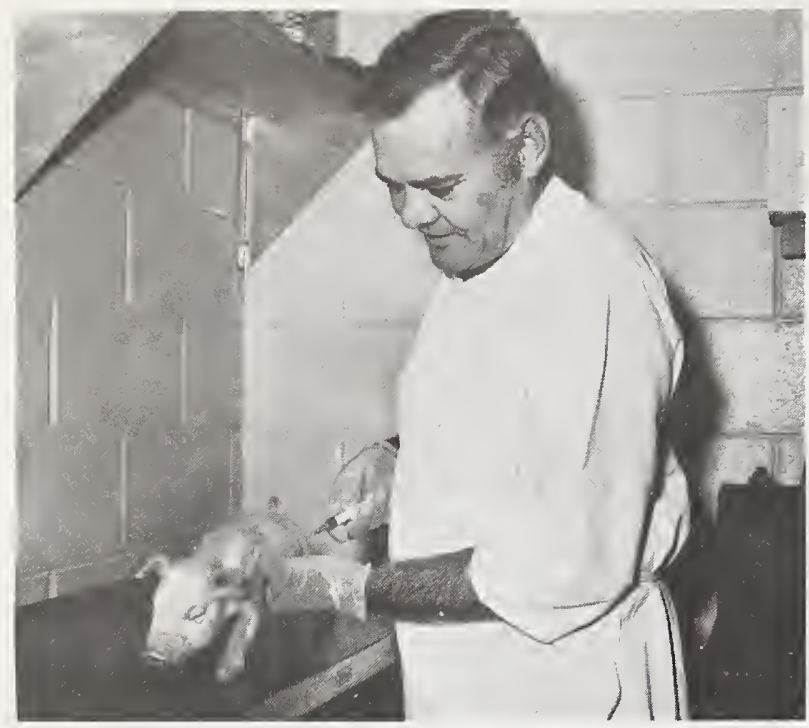

D. E. Gutekunst

pseudorabies antibodies in swine serum. Proc Ann Mtg US Anim Hlth Assoc 81:420-426. 1978 .

Gutekunst DE, Pirtle EC and Mengeling WL. Development and evaluation of a microimmunodiffusion test for detection of antibodies to pseudorabies virus in swine. Am J Vet Res 39: 208-210. 1978.

Gutekunst DE, Pirtle EC and Mengeling WL. Microimmunodiffusion test for detecting pseudorabies (Aujeszky's

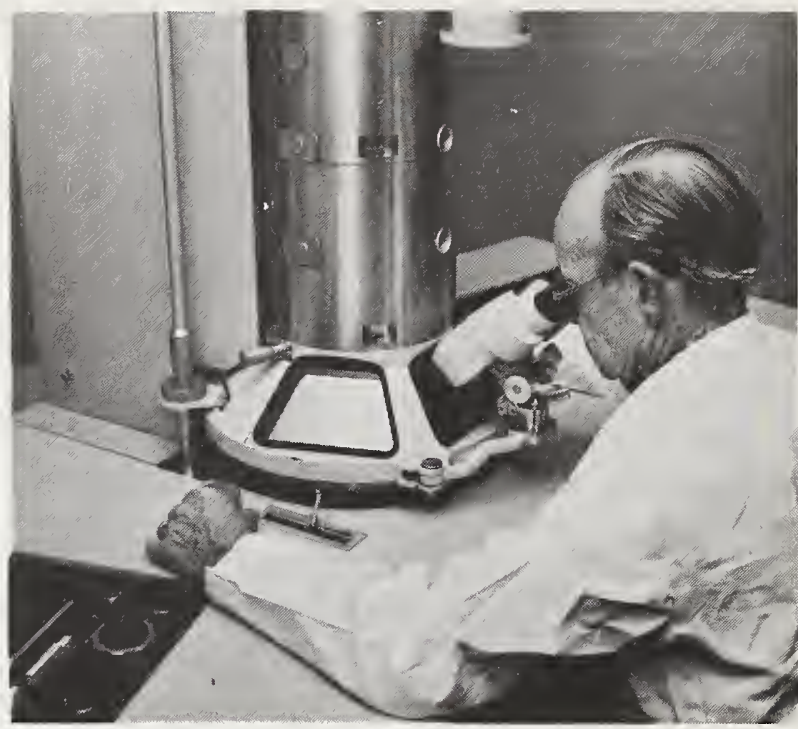

E. C. Pirtle

disease) viral antibodies. Proc 5th Intl Pig Vet Soc, Zagreb, Yugoslavia, KB.59. 1978.

Pirtle EC and Gutekunst DE. Virus isolation and immune responses in susceptible swine exposed with pseudorabies virus (Shope strain). Am J Vet Res 39:1367-1368. 1978.

Smith PC and Mengeling WL. A skin test for pseudorabies virus infection in swine. Can J Comp Med 41(4): 463-368. 1977.

\section{RESPIRATORY DISEASES OF CATTLE}

Staff:

KG Gillette, DVM, PhD

GH Frank, DVM, PhD, Dipl. ACVM JK Peterson, Technician

Current research on bovine respiratory disease is concerned with studying etiology, pathogenesis, and mechanisms of resistance to infection in the shipping fever complex and enzootic pneumonia of calves. Investigations on acute respiratory disease in transported (feeder) cattle implicate a multiplicity of causative agents including $P I-3, I B R, B V D$, RS viruses and Pasteurella hemolytica organisms . A detailed study of $\underline{P}$. hemolytica involved in respiratory tract disease resulted in developing a specific, rapid plate agglutination procedure for serotyping the organism. Some specific objectives of current research in bovine respiratory disease are (1) identifying specific infectious agents associated with the shipping fever complex; (2) studying mechanisms of infection and resistance in experimental infection with $\underline{P}$. 


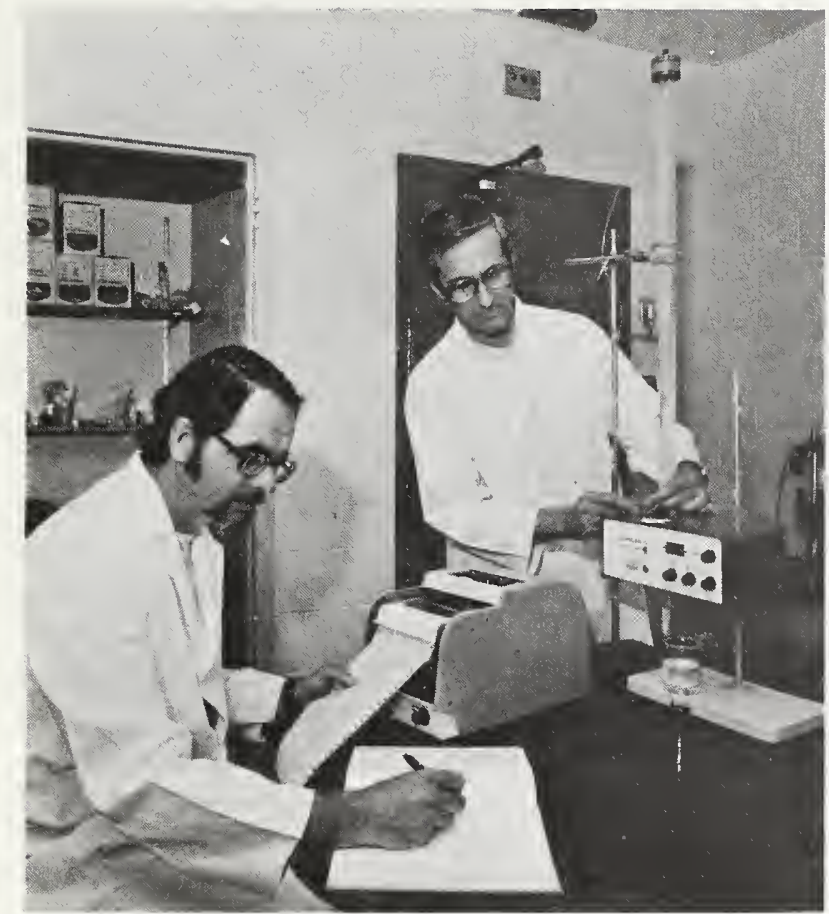

G. H. Frank, K. G. Gillette (clockwise)

hemolytica and with respiratory syncytial virus, and (3) developing reference reagents to study etiologic agents involved in the respiratory disease complex. A cooperative study on the relationship of environmental and transportation stress to immunity and resistance of feeder cattle to pathogens of bovine respiratory disease should provide new epidemiological information on multiple infections and serologic data on specific viral and bacterial agents.

Current Publications

Frank GH, Marshall RG and Smith PC. Clinical and immunological responses of cattle to infectious bovine rhinotracheitis virus after infection by viral aerosol or intramuscular inoculation. AJVR 38:1497-1502. 1977.

Lambert G. Bovine respiratory disease research at NADC. Proc Livestock Conservation Inst 62:115-118. 1978.

Smith PC. The bovine herpesviruses: An overview. Proc Ann Mtg US Anim Hlth Assn 80:149-158. 1977 .

Smith PC. Experimental infectious bovine rhinotracheitis virus infections of English ferrets (Mustela putorius furo L). AJVR 39:1369-1372. 1978.

Smith PC. Pathological and immunological changes in chemically induced recrudescence of infectious bovine rhinotracheitis virus infection in cattle. PhD Thesis, Iowa State University, Ames. 1977.

\section{PHYSIOPATHOLOGY RESEARCH LABORATORY}

Shannon C. Whipp, DVM, PhD--Chief Annete Bates--Secretary

Research is directed toward defining pathogenic mechanisms of infectious and noninfectious diseases of domestic animals. Research areas include (1) physiopathology of calcium, phosphorous, magnesium, and vitamin D metabolism (milk fever, grass tetany, rickets, oxalate toxicity); and (2) gastrointestinal physiopathology (intestinal transport processes, mechanisms of diarrheal disease, functional characteristics of intestinal microflora). Research areas include excellent surgical facilities, recording equipment, and variety of automated analytical technology. The following areas of expertise are available (1) anaerobic microbiology; (2) peptide hormone purification, bioassay, and radioimmunoassay; (3) quantitation of vitamin $D$ metabolites; (4) experimental surgery; (5) endocrinology; (6) in vitro and in vivo gastrointestinal physiology; (7) gnotobiology; and (8) radiotelemetry. 


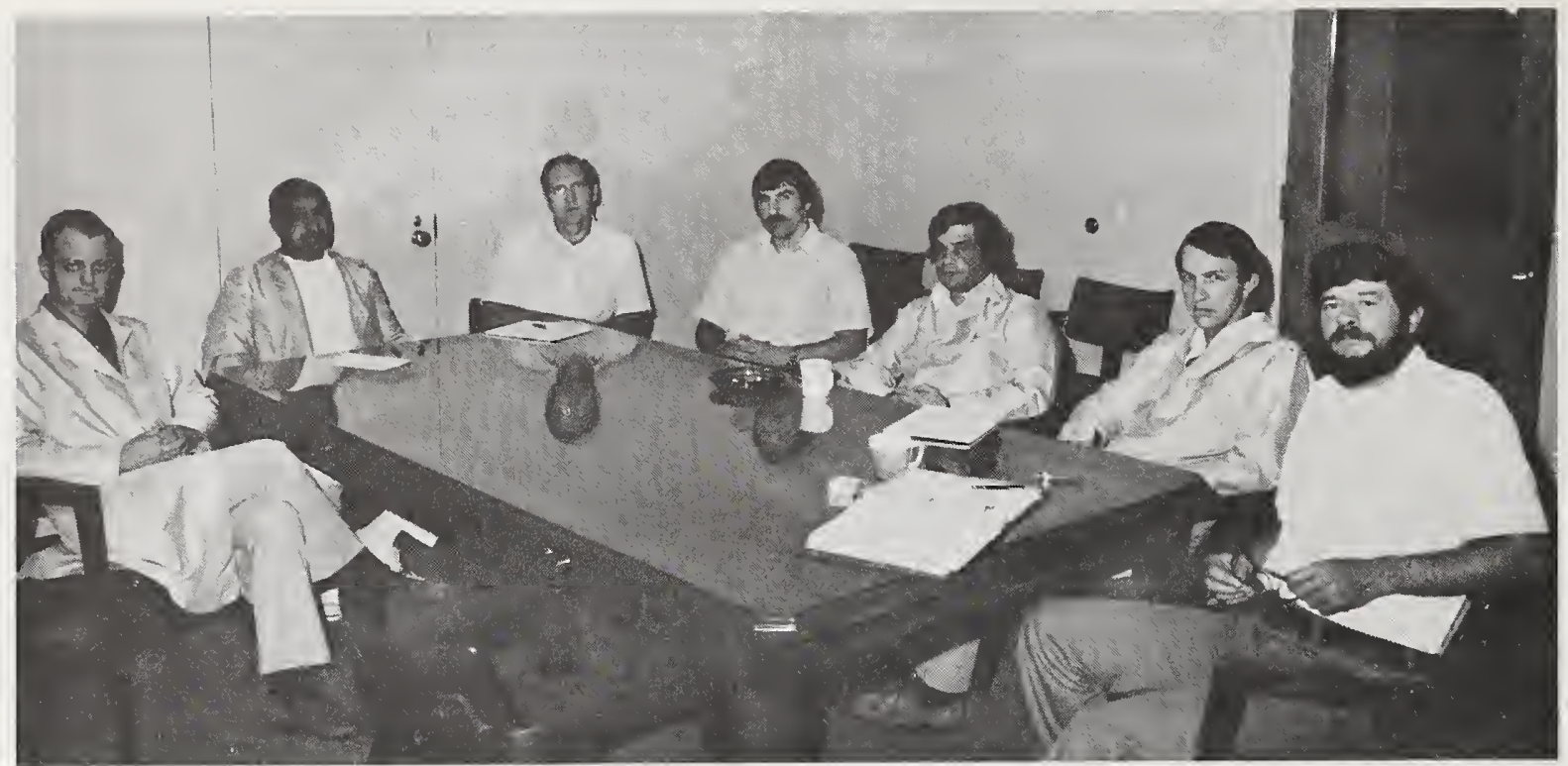

J. L. Riley, I. M. Robinson, E. T. Littledike, K. L. Horst, R. A. Argenzio, M. J. Allison, S. C. Whipp (clockwise)

Excellent opportunities exist for collaborative research in all areas of animal disease with other sections of this laboratory and with Iowa State University.

\section{GASTROENTERIC PHYSIOLOGY}

\section{Staff:}

SC Whipp, DVM, PhD

RA Argenzio, PhD

RW Morgan, Technician

DF Lebo, Technician

BW Mullen, RN

Emphasis in this area is placed on the study of normal gastrointestinal transport mechanisms and on diarrheagenic mechanisms in diarrheal diseases of domestic animals.

One of the current studies examines the range and magnitude of absorption and the physiological and pharmacological factors influencing absorption. These studies provide a framework for interpreting diarrheal mechanisms and their control. The pig is the primary experimental animal, but other species are used when a particular mechanism is exemplified.

A second project is concerned with elucidating the transport mechanism

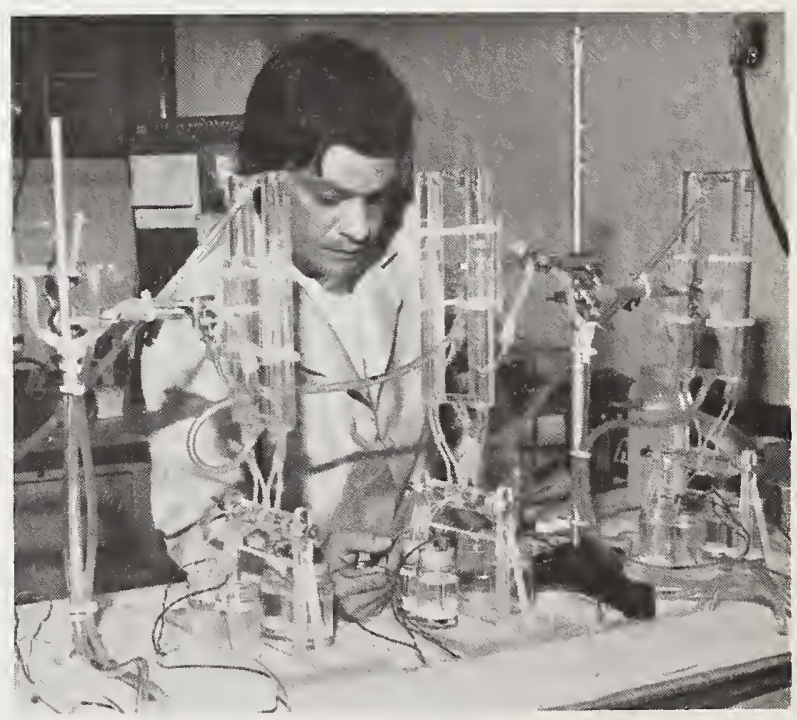

R. A. Argenzio 
and active secretory system responsible for the small bowel diarrhea elicited by enteropathogenic E. coli. Two porcine strains of heatstable enterotoxin have recently been purified and are currently being used in the studies.

Isolated loops of proximal jejunum are inoculated with enterotoxin, and the net changes in luminal contents are assessed. In addition, an in vitro method \& Ussing Chamber) is employed in which electrochemical gradients and other passive driving forces can be controlled.

Three areas of investigation have been conducted in examining the pathogenesis of swine dysentery. These are (1) changes in ion transport from isolated colonic loops, histopathological changes, and changes in blood chemistry in pigs infected with Treponema hyodysenteriae; (2) permeability changes in colonic mucosa of infected pigs; and (3) isotopic tracer studies of $\mathrm{Na}$ and $\mathrm{Cl}$ unidirectional fluxes from isolated colonic loops.

Key Publications

Whipp SC and Donta ST. Serum antibody to Escherichia coli heat-labile enterotoxin in cattle and swine. Am J Vet Res 37:905-906. 1976.

Whipp SC and Donta ST. Serum antibody to Escherichia coli heat-labile entero- toxin in cattle and swine. Am J Vet Res 37:905-906. 1976.

Current Publications

Argenzio RA. Physiology of diarrhealarge intestine. JAVMA 173:667672. 1978.

Argenzio RA, Southworth $\mathrm{M}$, Lowe JE and Stevens CE. Interrelationship of $\mathrm{Na}$, $\mathrm{HCO}_{3}$, and volatile fatty acid transport by equine large intestine. Am J Physiol 233:E469-E478. 1977.

Argenzio RA and Whipp SC. Pathophysiology of diarrhea. In Veterinary Gastroenterology. Edited by NV Anderson, Lee \& Febiger. 1978.

Cole HD, Staley $\mathrm{T}$ and Whipp SC. Reduction of reactivity of Escherichia coli enterotoxins by intestinal mucosal components. Infect Immun $16: 374-381$. 1977 .

Whipp SC. Studies on Escherichia coli heat-stable enterotoxin. Proc 4th Internat 1 Congress Internat Pig Vet Soc J 13. 1976. (Abstract).

Whipp SC. Physiology of diarrhea-sma11 intestine. JAVMA 173:662-666. 1978.

Whipp SC, Harris DL, Kinyon, JM, Songer JG and Glock RD. Enteropathogenicity testing of Treponema hyodysenteriae in ligated colonic loops of swine. Am J Vet Res 39:1293-1296. 1978.
MINERAL METABOLISM STUDIES

Staff:

ET Littledike, DVM, PhD

RL Horst, $\mathrm{PhD}$

CA Hauber, Technician

AC Wheeler, Technician

Our mineral metabolism project in- cludes studying the basic metabolism of calcium, phosphorous, and magnesium, as well as diseases of mineral metabolism in several animal species. These studies include measuring the parathyroid hormone, calcitonin, and vitamin $D$ and most of its known metabolites. Studying the basic regulatory interrelationships between 
these minerals and their regulatory hormones and vitamins provides a basis for evaluating defects that occur as a series of disease complexes in domestic animals.

A series of studies have been conducted on milk fever in dairy cattle with the ultimate objective of developing management techniques to effectively prevent this disease. These studies, which include defining the physiopathology of this disease, indicate that the basic problem is an inability to respond appropriately to the calcium demand that occurs when coincident with initiation of lactation begins. Several effective prepartum regimens have been devised to facilitate calcium mobilizing that include low calcium diets, prepartum milking, and administering vitamin D or certain of its metabolites.

Studies have also been conducted on the physiopathology of grass tetany and the metabolism of $\mathrm{Ca}$ and $\mathrm{Mg}$ in this condition. The primary mineral imbalances include hypomagnesemia, hypocalcemia, and low cerebrospinal fluid magnesium concentrates. It also appears that there is a defect in secretion of parathyroid hormone, which is secondary to severe hypomagnesemia. A defect in target tissue response to parathyroid hormone is also postulated. Thus, prolonged hypomagnesemia and hypocalcemia are present. Current studies include defining the changes in concentrations of vitamin $D$ and its metabolites, which occur in this condition.

A substantial effort is being made to characterize disease syndromes involving deficiencies or toxicities of vitamin $D$, which occur in domestic animals. Basic deficiency studies are being done in the pig. Neonatal pigs have low levels of the precursors for biologically active metabolites of vitamin D. These low levels are maintained until weaning time in pigs raised in confinement and fed standard commercial diets.

Thus, these studies have major implications regarding current husbandry practices. The pig appears to be an excellent model for studying the development of $D$ deficiency in several species. The sequence of changes in blood and bone that occur as young pigs develop rickets have been characterized. The physiopathology of spontaneous $D$ deficiency occurring in young pigs and turkeys is currently being characterized. Studies of pathogenesis of vitamin D toxicity in cows are in progress in which the vitamin $D$ metabolites responsible for the toxicity are being quantitated.

The pathogenesis of halogeton toxicity in sheep has been described.

Key Publications

Going RL, Jacobson NL, Beitz DC, Littledike ET and Wigger KD. Prevention of parturient paresis by a prepartum, calcium deficient diet. J Dairy Sci 57:1184-1188. 1974.

Littledike ET. Relationship of milk secretion to hypocalcemia in the dairy cow. J Dairy Sci 59:1947-1953. 1976.

Littledike ET, Glazier D, and Cook H. Electrocardiographic changes after induced hypercalcemia and hypocalcemia in cattle: Reversal of the induced arrhythmia with atropine. Am J Vet Res 37:383-388. 1976.

\section{Current Publications}

Cox P, Littledike ET. Techniques for sampling ventricular and cysternal cerebrospinal fluid from unanesthetized cattle. Lab An Sci 28:465-469. 1978.

Haussler M, Hughes M, Baylink D, Littledike ET, Cork D, Pitt M. Influence of phosphate depletion in the 
biosynthesis and circulating level of 1,25-dihydroxyvitamin D. Phosphate Metabolism, Proceedings of 2nd Interntl Workshop on Phosphate,
Heidelberg, Germany, June 1976. SG Massey and E Ritz (eds), published by Plenum Press New York, pp 233-250. 1977.

\section{GASTROINTESTINAL MICROBIOLOGY}

Staff:

MJ Allison, $\mathrm{PhD}$

IM Robinson, MS

$\mathrm{K}$ Sawson, Ms

HM Cook, Technician

JA Bucklin, Technician

One area of investigation concerns the interactions between gastrointestinal microbes and toxic substances. Most of our effort to date has been directed toward obtaining an understanding of such activities in the rumen. For example, we found that ruminal microbial populations able to degrade oxalic acid at greatly increased rates are selected when plants containing high amounts of oxalic acid are included in the diet of either cattle or sheep. Degradation involves interactions between several microbes. The nature of these interactions, the factors involved in selecting competent species, and identifying the active agents are being investigated. Other interactions that have been studied include degradation of botulinum toxin and of aflatoxin $B_{1}$, and work is planned with nitrate-nitrite metabolism.

A second goal of the project is to describe the gastrointestinal population of the cecum and colon of swine in both taxonomic and physiologic terms. The predominant bacteria are fastidious anaerobes but, at present, information concerning them is limited. Work is in progress to classify a large number of isolates from both normal pigs and pigs with swine dysentery. This work also involves culture and scanning electron microscopic studies of bacterial populations attached to cecal and colonic mucosa. Current studies also involve measuring rates of organic acid produced in the lower bowel of pigs fed either high or low fiber diets. These studies are designed to permit an estimate of the significance of this production to the energy metabolism of swine.

A third area of investigation is directed toward defining the etiology of swine dysentery. Current studies involve using gnotobiotic pigs to define the anaerobic flora that participate synergistically with Treponema hyodysenteriae in the pathogenesis of this disease.

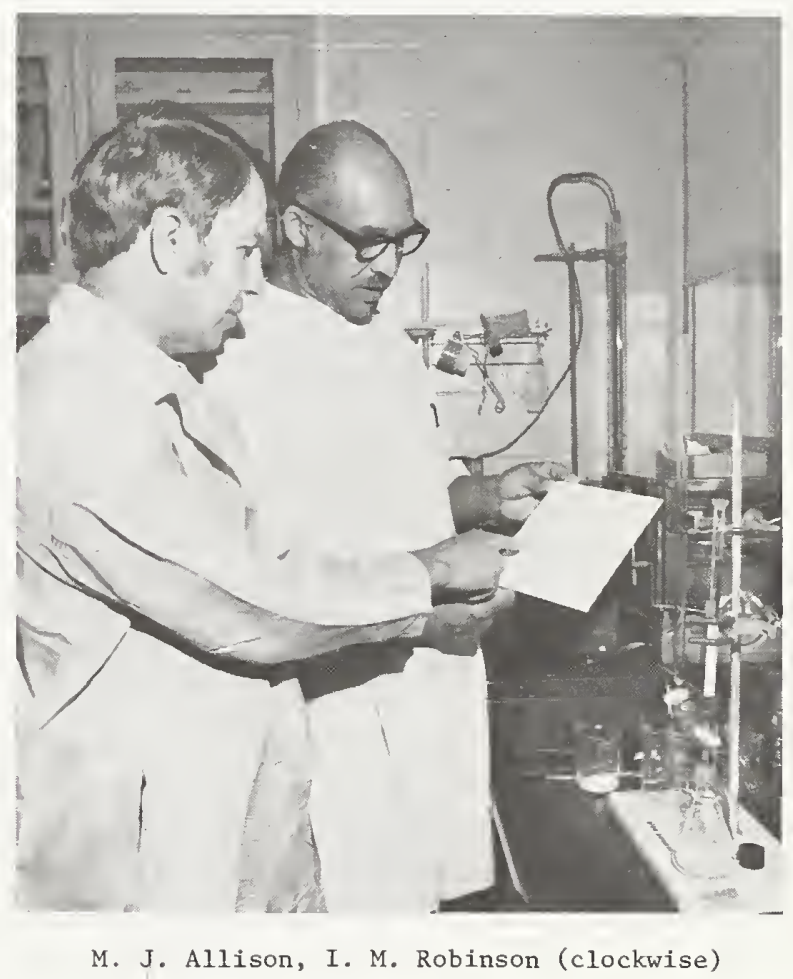


Anerobes, which have been found to be present in high numbers in colonic epithelium of conventional pigs with clinical swine dysentery, are being evaluated individually and in various combinations for the ability to induce colonic lesions in germ-free pigs when T. hyodysenteriae is present. The ultimate goal of this project is to define the mechanism through which these organisms cause damage to colonic epithelium and epithelium function.

Rumen anaerobic mycoplasma are also being studied. The characteristics of these organisms, their nutritional requirements, and their ecological role in rumen microflora are being defined.

\section{Current Publications}

Allison MJ. Production of branchedchain volatile fatty acids by certain anaerobic bacteria. Appl Environ Microbio1 35:872-877. 1978.

Allison MJ, Dawson KA, Cook HM. Ruminal oxalate degradation: Studies with continuous and enrichment cultures. Report on Conf. on Rumen Function, Chicago, IL, Nob 30Dec 1, 1977. (Abstract)

Allison MJ, Maloy SE, Matson RR. Inactivation of Clostridium botulinum toxin by ruminal microbes from cattle and sheep. Appl Environ Microbiol 32:685-688. 1976.
Allison MJ, Littledike ET, James LF. Changes in ruminal oxalate degradation rates associated with adaptation to oxalate ingestione. J Anim Sci 45: 1173-1179. 1977.

Allison MJ, Robinson IM, Bucklin JA. Characterization of the predominant bacteria of the cecum and colon of swine. 58th Conf of Res Workers in Animal Dis, Nov 28-29, 1977. (Abstract)

Dawson KA, Allison MJ. Inhibition by hydrogen and continuous culture of an anaerobic oxalate-degrading population. Abstracts of 78th Ann Mtg of Am Soc Microbiol, p 88. 1978 (Abstract).

Harris DL, Alexander TJL, Whipp SC, Robinson IM, Glock RD, Matthews PJ. Swine dysentery: Studies of the inoculation of gnotobiotic pigs with Treponema hyodysenteriae, Bacteroides fragilis, and Fusobacterium necrophorum. JAVMA 172:468-471. 1978.

Robinson IM, Allison MJ. Lipid requirement for growth of Aneroplasma abactoclasticum. Abstracts of the Ann Mtg of the Am Soc Microbiol. 1977 (Abstract).

Robinson IM, Rhoades KR. Serological relationship between strains of anaerobic mycoplasmas. Int J Syst Bacteriol 27:200-203. 1977.
DEVELOPMENT OF RADIO TELEMETRY SYSTEM FOR TRANSMITTING PHYSIOLOGIC DATA

Staff:

JL Riley, MS

Radio telemetry systems are being developed and used at NADC to record physiologic data from normal and diseased animals without restraint.
Transmitters monitor temperature, EKG, respiration rate, blood pressure, rumen motility, and EEG. Present emphasis is on developing data acquisition systems to reduce data by computer analysis. In the future, longer-range, longer-life transmitters are to be developed so data nay be recorded from animals at greater distances from the receiver. 


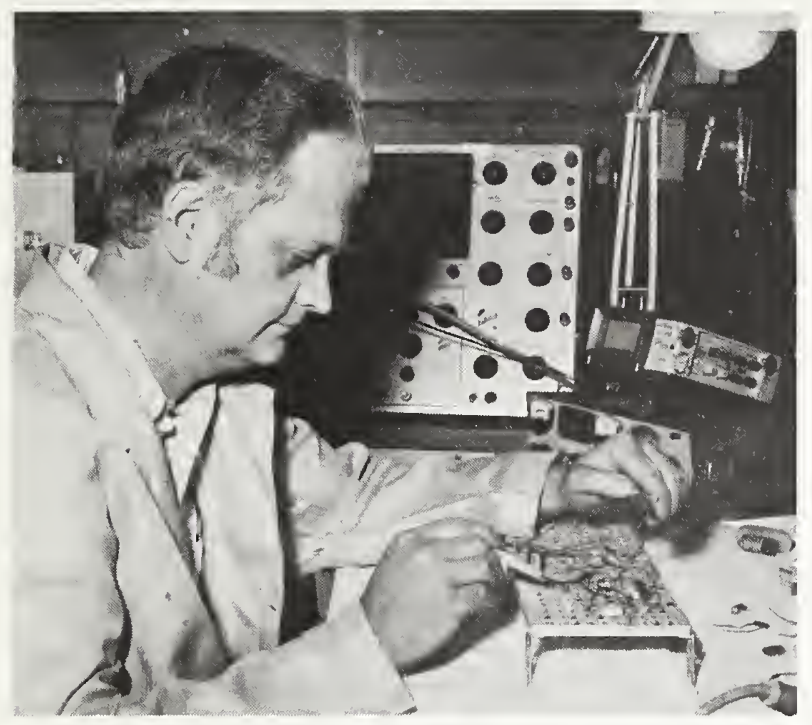

J. L. RIley

\section{Key Publications}

Dougherty RW, Riley JL, Cook HM. Gastrointestinal motility in the ruminant: Influence of the nature of feed. Recherches Veterinaires M 22. 1976.

\section{Current Publications}

Brown RW, Thomas JL, Cook HM, Riley JL, Booth GD. Effect of environmental temperature stress on intramammary infections of dairy cows and monitoring of body and intramammary temperatures by radiotelemetry. Am J Vet Res 38:181-187. 1977.

Merkal RS, Lepper AWD, Hintz AM, Riley JL. Comparison of techniques for measuring the local and systemic response to tuberculin in cattle. Am J Vet Res 38:113-116. 1977.

Riley JL, Thurston JR, Egemo CL, Elliott HL. A radiotelemetry transmitter for transmitting temperatures for small animals. J Appl Physiol 45:1016-1018. 1978.

\section{BIOLOGICAL SAFETY UNIT}

JF Sullivan--Safety officer

KA Burke--Secretary

In the biological safety unit of NADC we are concerned with identifying, assessing, and controling hazards associated with research and regulatory activities carried on within the Center. Safety research programs are designed to protect Center employees from zoonotic disease agents under investigation and to prevent the unplanned contamination or infection of laboratory media or animals used in experiments, diagnostic or biologics assay programs. Major research areas include evaluating disinfectants and disinfecting procedures; developing sterilization criteria for biological materials and other contaminated materials with heat or ethylene oxide; constructing and evaluating cages; exposing chambers and other containment systems, as well as the design and fabrication of safety pipettors, formaldehyde generators, and other safety equipment items. Independent and cooperative studies involving the behavior infectivity and pathogenicity of biological or toxic aerosols are also investigated or supported by this unit.

Senior staff members serve as technical advisors to other SEA and USDA agencies with respect to the design and operation of biological safety laboratories and the control of hazards attending work with biological systems. They also serve as consultants to numerous federal, state, and private agencies in matters pertaining to biological and laboratory safety. 


\section{BIOLOGICAL LABORATORY SAFETY RESEARCH}

\section{Staff:}

JL Sullivan, DVM, MS

JR Songer, MS

DL Braymen, MS

RG Mathis, BS

TP Nelson, Technician

\section{Aerosol Studies}

In this study, we investigated the effects of ionized air on mechanically generated aerosols in pens equipped with a corona discharge negative-air ionizer and a 6,000 volt positively charged wall panel. Tests conducted under these conditions reduced aerosol by 90 percent. In static chamber studies employing viable fungal spores, 90 percent count reductions $\left(1 \times 10^{5: 8}\right.$ to $\left.1 \times 10^{4.8}\right)$ were achieved at the end of 4-minute exposure to ionized air.

\section{Containment Equipment Systems}

A Class I containment cabinet system was fabricated for work with avian tuberculosis. This system was designed to contain hazardous aerosols generated in the commercial operations relating to the initial handling, grinding, casing and smoking of hot dogs.

A Class III, or gas tight containment cabinet and aerosol exposure system, was developed for work with moderate to high hazard agents and toxins. This system is currently being used in studies involving exposure of laboratory animals to carcinogenic aflatoxins.

\section{Current Publications}

Songer JR. Safe convenient portable pipettor. App1 and Environ Microbiol 35:5:974-975. 1978.

Songer JR, Mathis RG, Nelson TP. Autoclavable ultrahigh efficiency filter for use with flexible film germ-free animal isolators. Lab An Sci 28:6:757-759. 1978 .

Sullivan JF, Songer JR, Estrem IE. Laboratory-acquired infections at the National Animal Disease Center, Health Laboratory Science 15(1):58-64. 1978.

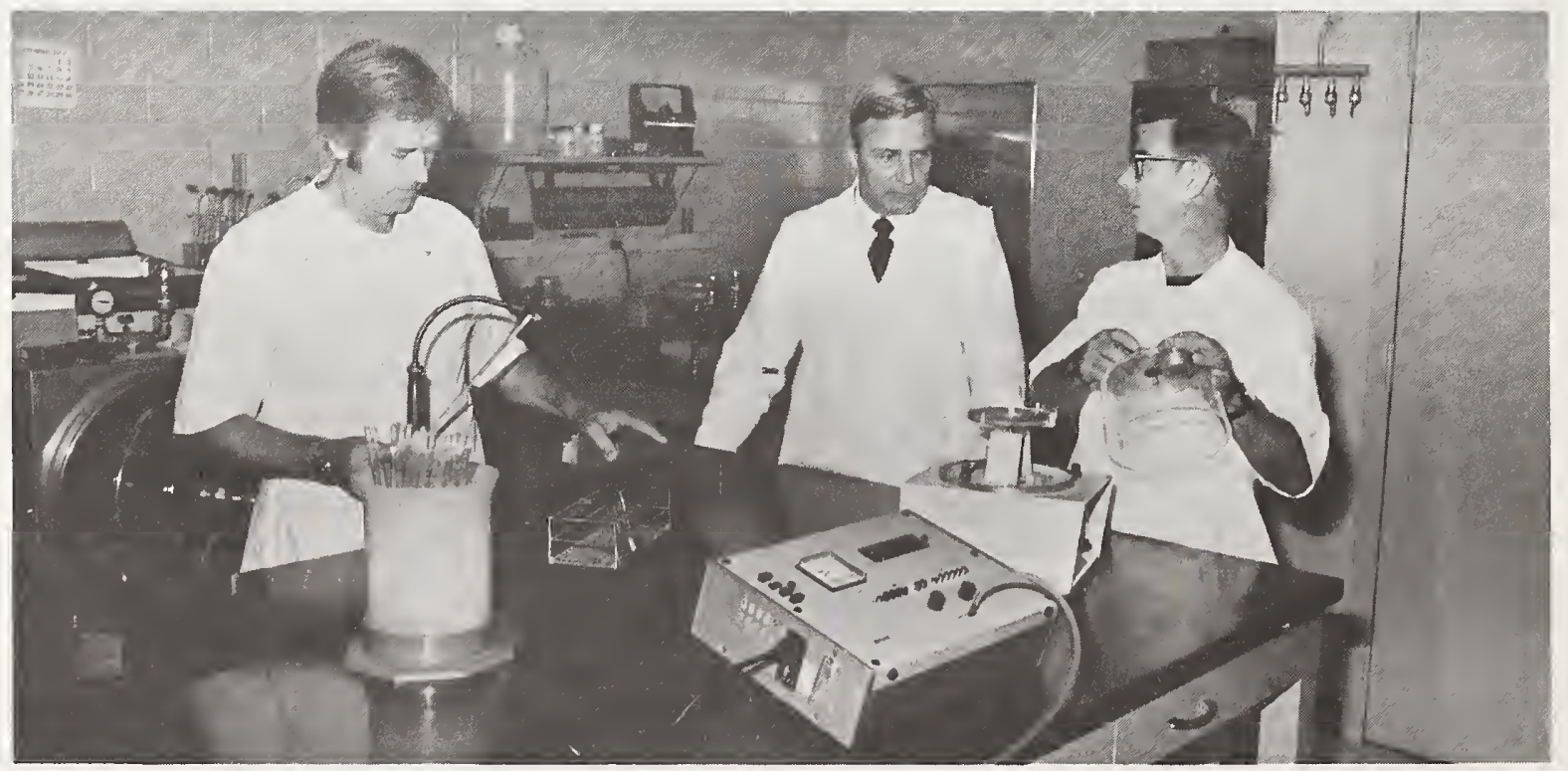

J. R. Songer, J. F. Sullivan, D. T. Braymen (left to right) 


U.S. DEPARTMENT OF AGRICULTURE SCIENCE AND EDUCATION ADMINISTRATION NORTH CENTRAL RECION

NATIONAL ANIMAL DISEASE CENTER

P.O. BOX 70

AMES, IOWA 50010

OFFICIAL BUSINESS

PENALTY FOR PRIVATE USE $\$ 300$
POSTAGE AND FEES PAID

U.S. DEPARTMENT OF AGRICULTURE

AGR 101
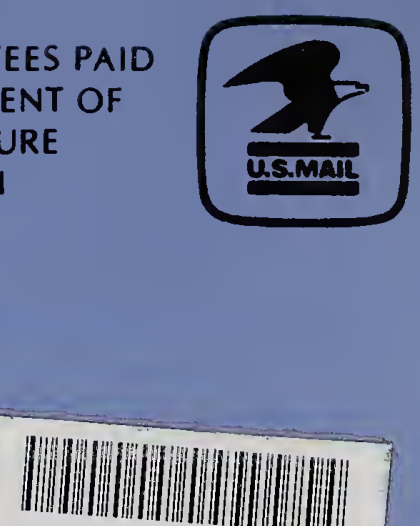

ROOOI 027958 